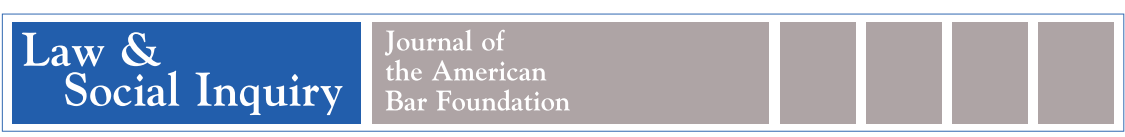

Law Eु Social Inquiry

Volume 43, Issue 3, 981-1026, Summer 2018

\title{
The Integration of Law into Global Business Solutions: The Rise, Transformation, and Potential Future of the Big Four Accountancy Networks in the Global Legal Services Market
}

\author{
David B. Wilkins and Maria J. Esteban Ferrer
}

\begin{abstract}
Using a unique data set comprised of original research of both the corporate Web sites of the Big Four-PwC, Deloitte, KPMG, and EY-and their affiliated law firms, as well as archival material from the legal and accountancy press, this article documents the rise and transformation of the Big Four legal service lines since the enactment of the Sarbanes Oxley Act of 2002. Moreover, it demonstrates that there are good reasons to believe that these sophisticated players will be even more successful in penetrating the corporate legal services market in the decades to come, as that market increasingly matures in a direction that favors the integration of law into a wider category of business solutions that these globally integrated multidisciplinary practices now champion. We conclude with some preliminary observations about the implications of the reemergence of the Big Four legal networks for the legal profession.
\end{abstract}

\section{INTRODUCTION}

Throughout the 1990s, the Big Five accounting firms-Arthur Andersen, KPMG, Ernst \& Young (EY), PricewaterhouseCoopers (PwC), and Deloitte-made a concerted effort to enter the legal services market. This effort was particularly pronounced-and particularly successful-in Europe, but the Big Five pushed aggressively to win the right to provide legal services in virtually every important legal market around the world, including the United States. By the close of the twentieth century, legal networks directly owned or closely affiliated with the Big

David B. Wilkins is the Lester Kissel Professor of Law, Faculty Director of the Center on the Legal Profession, and Vice Dean for Global Initiatives on the Legal Profession at Harvard Law School. He may be contacted at dwilkins@law.harvard.edu.

Maria J. Esteban Ferrer is a Lecturer at the Department of Law at ESADE, Universitat Ramon Llull, an Affiliated Researcher at the Harvard Law School Center on the Legal Profession, and CoDirector of the Center's Big Four Research Project.

The authors thank participants at the Inspiring Futures Workshop at ESADE Law School, Universitat Ramon Llull; the participants at the Novak Druce Conference on the Success and Failure of Professional Firms, at Saïd Business School, University of Oxford; the International Legal Ethics Conference panel on the Role of Multidisciplinary Practices in the Globalized Legal Services Industry, hosted by the Stein Center for Law and Ethics, Fordham Law School; and the Harvard Law School Center on the Legal Profession's Working Paper Series, as well as the readers of The Practice issue on the reemergence of the Big Four in the global legal services market for their helpful comments on earlier drafts of this article.

[The copyright line for this article was changed on 4 August 2017 after original online publication]

(C) 2017 The Authors. Law \& Social Inquiry published by Wiley Periodicals, Inc. on behalf of American Bar Foundation.

This is an open access article under the terms of the Creative Commons Attribution-NonCommercial-NoDerivs 
Five were major players in many countries, and were threatening to enter those like the United States from which they were still barred. However, all this appeared to change after the wave of accounting scandals arising out of the 2001 financial crises. These scandals, which brought down Arthur Andersen and ushered in regulatory reforms in the United States and other countries around the world designed to place severe restrictions on the ability of the remaining Big Four to offer nonauditing services to their audit clients, appeared to signal the death knell for the Big Four's legal networks. According to most observers, in the post-Sarbanes-Oxley era the accounting firms are no longer significant participants in the global market for legal services.

In this article, we document that reports of the death of the Big Four legal networks are, to paraphrase the American humorist Mark Twain's famous retort when told about a newspaper story reporting his own demise, "greatly exaggerated" (Twain 1906, 160). Using a unique data set consisting of original research from the corporate Web sites of the Big Four and their affiliated or strategic partner law firms, as well as archival material accessible on the Internet from the legal and accountancy press, we demonstrate that far from being dead, in recent years the legal service lines linked to the international accountancy networks have grown significantly in size, scope, and importance. Nor is this growth confined to tax or taxrelated advisory services, where the accounting firms are generally thought to have a natural competitive advantage. Although tax services remain an important cornerstone, as shown in Appendix 1, by 2011, the Big Four legal networks were already important players in a variety of legal fields, including fast-growing areas (e.g., employment and immigration law, restructuring and insolvency law, and technology, media, and telecommunications law) as well as high-end practices, such as corporate mergers and acquisitions (M\&A), capital markets, and finance law. Moreover, as impressive as their expansion has been over the last decade, we argue that there are good reasons to believe that the Big Four will be even more successful in penetrating the corporate legal services market in the decades to come.

As this market globalizes and matures, it is increasingly moving in a direction that favors the approach to integrating law into a wider category of business solutions that these globally integrated multidisciplinary firms now champion. Both current and likely future economic and regulatory changes are creating an environment that is particularly advantageous to the approach to delivering legal services currently being developed by the Big Four. As Alexandru Reff, Partner-inCharge of Deloitte's Romanian Tax \& Legal Practice, makes clear: "Deloitte aims at developing the largest legal network in the world, and also at building the legal practice of the future, with global presence, ability to understand businesses and operate pragmatically, in close connection with experts from other areas, at costs optimized through efficient processes and technologies" (Deloitte 2013e).

Only time will tell whether this confident claim comes to fruition-this is, after all, not the first time that the large accountancy firms have predicted that they would assume a dominant position within the legal marketplace. However, the fact that these large and well-financed players are pursuing a strategy that is very well suited for the new climate of more for less and that even the most skeptical observers concede is reshaping the global market for corporate legal services suggests 
that the Big Four's attempt to capture a significant share of the market may very well be more successful this time around. In the 1990s, the accounting firms attempted to enter the legal services market by aping the ways of large law firms, which at the time were universally acknowledged to be the market leaders.

In the second decade of the twenty-first century, it is now large law firms who are attempting to demonstrate that they can provide the seamless integration of law into effective global business solutions with the same degree of "global presence, ability to understand businesses and operate pragmatically, in close connection with experts from other areas, at costs optimized through efficient processes and technologies" (Deloitte 2013e) that are currently being promised by the increasingly large and empowered Big Four. Ironically, by increasingly making themselves look like the Big Four in how they define and deliver legal services, large law firms may actually be hastening a world in which these global giants will no longer have to disguise their ambitions from regulators and the public, thereby making them even more potent competitors for a growing share of the corporate legal market that clients view as being at the intersection of law, business, tax, information technology, and process management.

The rest of our argument proceeds as follows. Section II (Historical Background) provides a brief overview of the history of the competition between accountants and lawyers prior to the passage of the Sarbanes-Oxley Act of 2002 (SOX) in the United States and other similar regulatory reforms in other countries designed to limit the ability of the Big Four to deliver nonaudit services to their audit clients. As indicated above, this history tells a familiar story in which the major accounting firms attempted to exploit the natural overlap between accounting, tax, and legal services to build separate legal services lines that would compete with traditional law firms - and how that effort was eventually thwarted by regulatory changes following Enron and other corporate scandals that were widely blamed on a perceived conflict of interest caused by accounting firms simultaneously selling other professional services (most notably consulting services) to their audit clients.

In Section III (Life After SOX), we use original research from the corporate Web sites of the Big Four and their affiliated and strategic partner law firms over several years to demonstrate that notwithstanding these regulatory changes, the Big Four's legal networks have not only survived, but have also become larger and more successful than they were during the 1990s-albeit often in ways that are less visible, and less independent, than the legal services lines that existed prior to SOX.

In Section IV (How Did This Happen?) we explain how the Big Four were able to achieve their current position in the market for legal services notwithstanding numerous attempts to ban them from the field. Specifically, we identify changes in four interrelated arenas that have allowed the accountants to grow their legal offerings under the radar screen - and that seem likely to accelerate their growth in the coming years: (1) current gaps in the scope of existing regulation on auditor independence that have allowed the Big Four to continue to operate their legal services businesses; (2) increasing government intervention in the market for legal services, and a corresponding trend toward deregulation - a trend that ironically has been supported by both law firms and accounting firms; (3) globalization and the shift in economic activity to emerging markets, where there is less regulation 
prohibiting the Big Four's legal networks from operating, and more desire by global clients for solutions that integrate law into standard business practices; and (4) the evolution of the Big Four's business model, which has transformed them from accounting firms, to multidisciplinary professional service firms, to organizations offering integrated global business solutions to complex problems at the intersection of finance, tax, strategy, organization, and, increasingly, law-at the same time that law firms are trying to market themselves as global business partners.

Finally, Section $\mathrm{V}$ concludes by discussing some of the implications of the reemergence of the Big Four as major players in the market for legal services for clients, professionals, regulators, scholars, and the public. Although it is far from certain the extent to which the Big Four will be able to displace law firms and other established providers in many areas, their growing size, sophistication, and increased transparency on the Internet seems likely to further the integration of law-and therefore legal providers-into global business processes that lie outside the control of lawyers.

\section{HISTORICAL BACKGROUND}

There is an inevitable overlap between the fields of accounting and law. To audit and present a company's financial position properly, an auditor must understand and be able to apply the legal rules that govern such disclosures. Similarly, to advise a company on a broad array of corporate matters, ranging from regulatory compliance to $M \& A$, properly, a lawyer must have at least a rudimentary understanding of the company's balance sheet and financial performance. Not surprisingly, lawyers and accountants have always competed over which profession should control this contested domain.

The most relevant example of interprofessional competition between lawyers and accountants is in the field of tax advisory services, a professional territory at the intersection of law and finance that emerged internationally during the early twentieth century as capitalist states implemented income taxation to "finance the welfare-warfare state" (Picciotto 1995, 27). The competition between accountants and lawyers over this contested domain produced different resolutions in different countries (Picciotto 1995; Rogowski 1995; Marcos 2000; Nnona 2006), but by the mid-twentieth century, in virtually every jurisdiction accounting firms controlled most or all of the field of tax advisory services with the exception of the high-end tax work done by large law firms and specialized tax boutiques (Picciotto 1995; Garth and Silver 2002; Dezalay and Garth 2004).

The large accounting firm's expansion in the field of tax advisory services during the latter decades of the twentieth century was not simply driven by the growing demand by global clients for the kind of tax services they could provide. It was also fueled by the declining profitability of their core accounting practice. Notwithstanding their near monopoly power in the field of auditing large publicly traded companies, the price companies were willing to pay for these services was declining rapidly. As a result, the Big Five (as they were then) went in search of related areas where they could leverage their audit client base to provide other, more lucrative 
professional services. By the 1980s, all the large accounting firms offered to their broad audit client base a growing arsenal of nonaudit consulting services, particularly in the areas of information technology and financial management (Zeff 2003; Holtzman 2004). Moreover, some of the most profitable of these areas intersected significantly with law, such as corporate restructuring, insolvency, litigation support, and forensic accounting services (Boyd 1999; Hinings, Greenwood, and Cooper 1999; Nnona 2006). In recognition of this new reality-and to exploit its potential-the Big Five ceased calling themselves accounting firms and began marketing aggressively as a new brand of multidisciplinary professional service organizations (Greenwood and Suddaby 2006) —or as Paton (2010, 2200) defines it, as "an integrated entity that provides legal services as one of several professional services offerings through a single firm or provider."

The Big Five began this transformation in civil law countries, where the legal profession was very fragmented. In these countries, lawyers had traditionally focused on litigation, thus showing a historical distance from counseling clients on business transactions. As a result, the bars in these jurisdictions had few rules specifically allowing or prohibiting multidisciplinary practices (MDPs) (Mullerat 1999; Nnona 2006).

The success of the accounting-led corporate and commercial law practices in the Continental European legal market of the 1990s has been well documented (Terry 1999, 2000; Stephen 2002; Panteia and Maastricht University 2012). By the mid-1990s, however, the Big Four also began to plant their flags in the common law world. Arthur Andersen was the first to act. In 1993, Andersen established an affiliated law firm in the United Kingdom, in a move subsequently described by The Lawyer (2007a) as the first step in what Andersen "hoped would be a globally dominant multi-disciplinary partnership (MDP).” It was not long before Price Waterhouse and Coopers \& Lybrand (before the two firms merged) had set up their own associations with UK law firms. By the turn of the century, KPMG, which in 1999 launched KLegal, and Ernst \& Young also joined the party by setting up their own affiliated legal entities in the United Kingdom (Lawyer 1996b, 2007b; Lindsay 1997a, 1997b). Only Deloitte claimed that it had no intention of extending to the United Kingdom (Lawyer 1996a; Hoult 1998). For the four firms that did, establishing a beachhead in the United Kingdom was central to their ambitions of building world-class legal networks (Lawyer 1996b; Power 2003).

As the accountancy firms trained their sights on the world's most important legal market - the United States - they undertook additional steps designed to give their legal networks legitimacy with both clients and regulators. To minimize the appearance of conflicts of interest with their core auditing business, the four firms that had entered the UK legal market began to integrate their affiliated law firms under the umbrella of separately branded legal networks-Andersen Legal, Landwell, KLegal, and E\&Y Law-all led by star lawyers. Thus, Andersen Legal recruited Tony Williams, former managing partner of the UK Magic Circle firm Clifford Chance, to be its worldwide managing partner. Similarly, Nick Holt, KLegal's UK managing partner, was the former founding partner of Weil, Gotshal \& Manges' London office. The strategy behind this shift in organization and recruiting was simple: look as much like a traditional law firm as possible (Garth 
2004). As a lawyer working at one of these legal networks succinctly explained, "if you are competing with a law firm, you've got to look like a law firm" (Garth and Silver 2002, 917). To accomplish this goal, the Big Five were willing to invest huge amounts of money to recruit top lawyers (Lawyer 2000; Law Society Gazette 2001). The result was a concerted public relations campaign to portray the Big Five legal networks as just more top firms—only bigger (Landwell 2001).

This charm offensive, however, failed to impress the American Bar Association-or the Congress of the United States. Based on a rendition of what it considered the core values of the legal profession-conflict of interest, independence, and client privilege-in 2000, the American Bar Association's House of Delegates rejected the recommendation of its own Commission on Multidisciplinary Practices that the Model Rules of Professional Conduct be amended to permit integrated MDPs (Paton 2010). At the same time, by the dawn of the twenty-first century, growing concerns over auditor independence and objectivity pushed Arthur Levitt (2000), the Securities and Exchange Commission (SEC) chairman, to propose rules barring accountancy firms from providing consulting services to their audit clients. Although Levitt's proposals were initially watered down by the lobbying efforts of the Big Five, when Enron and WorldCom collapsed, "[t]hese events brought tremendous investor uncertainty in the capital markets and created a crisis of credibility for the accounting profession not experienced since the 1929 stock market crash" (Reckers et al. 2007, 629). As a result of these high-profile audit failures, Arthur Andersen was criminally indicted, and eventually was forced to declare bankruptcy.

The US Congress reacted to these events by passing SOX. One of the central goals of this legislation was to put an end to a century of self-regulation by accountants. SOX therefore created a Public Company Accounting Oversight Board (PCAOB) to oversee implementation of standards and ethics rules related to audit practice aimed at strengthening auditor independence. Specifically, SOX established certain types of nonaudit services as off-limits to audit firms that provided auditing services to a public company, including legal services unrelated to the audit (Paton 2006). The goal was clear: to put an end to "the Big Five's version of the multidisciplinary practice" (Greenwood and Suddaby 2006, 35). Following SOX, similar laws prohibiting the provision of specific nonaudit services by a public company's auditor were enacted in many countries worldwide, including Mexico, Germany, China, Japan, France, Australia, and Canada (Tafara 2006). Between these legislative changes, and the organized bar's efforts to bury the now Big Four's legal ambitions in an avalanche of "core values rhetoric," the future of these networks seemed bleak indeed (Paton 2010, 2193).

\section{LIFE AFTER SOX}

The immediate aftermath of SOX appeared to provide ample support for this gloomy assessment. Prior to 2002, the Big Four's legal networks had grown to be as large as the largest law firms in the world: KLegal had 3,000 lawyers working in sixty countries; E\&Y Law 2,700 lawyers in seventy countries; Landwell (PwC) 
2,800 lawyers in some forty countries, with Deloitte Legal set to follow its rivals' expansionist strategies (Baxter and Tromans 2003; Tromans, 2003a, 2003b; Griffiths 2004). But in the years following SOX, the Big Four unbundled their legal networks - or so it seemed. The logic behind these actions seemed both impeccable and indisputable. As no less an authority than The Economist (2003) confidently declared: "When law firms hardly benefit from accountants' huge client base and accountancy firms are allowed to offer legal services only to a few clients, there is little point in accountants having a legal arm. Moreover, law firms have themselves become more global in recent years and many do not need the accountancy giants' international reach. 'Accountancy firms' drive in the legal arena is dead,' says John Malpas of Legal Week, a trade publication."

But as the old saw goes, predictions are hard-especially about the future. ${ }^{1}$ As we demonstrate in the following section, the many confident predictions in 2003 about the death of the "[a]ccountancy firms' drive in the legal arena" have proven to be far less accurate than even the most cautious futurist would have believed possible.

\section{Research Methodology}

To investigate the current state of the Big Four's legal networks, we examined the corporate Web sites of the Big Four and their affiliated and strategic partner law firms over several years. A corporate Web site has been compared to a "virtual storefront" (Halliburton and Ziegfeld 2009, 912) used by companies to promote their products and services (Zhao, Truell, and Alexander 2006). Ultimately, corporate Web sites offer an "approved, official and formalized" account (Bondy, Matten, and Moon 2004, 451) "of how the company wishes to be viewed, thus making them a broad-based tool for information dissemination" (Basil and Erlandson 2008, 127). Furthermore, the combination of this source of information with the analysis of archival material allows developmental insight into "hard-to-reach populations or sensitive topics" (Irwin 2013, 296).

From July 2011 to February 2012, the corporate Web sites of PwC, Deloitte, KPMG, and EY, as well as the Web sites of their affiliated and associated law firms were independently and consecutively identified through Google Search (see Appendix 2). We collected the following data from these sources: location where legal services were promoted-global site, regional site, and individual country site; firm mentioned on the Web as providing legal services-if any; the Web path to access legal services; the list of law practices on offer; and the general textual description of the legal services. Due to the dynamic nature of Web sites (Llopis, González, and Gascó 2009), the collected data were updated over a two-week period in March 2012 by revisiting all the previously analyzed Web pages. One author conducted the actual exploration of the Web sites using the same IP address to assure consistency in the criteria used for data collection. Although the textual

1. For the long list of people to whom this quote is attributed, see http://www.larry.denenberg.com/ predictions.html. 
information provided on the Web sites was taken into account, the analysis is largely descriptive and relies heavily on the use of frequencies and percentages. Following Meyer (2008), this section can be categorized as descriptive of information available through the corporate Web sites of the Big Four and their affiliated or associated law firms.

Since a Web site is a hierarchy of information connected via hyperlinks to other sites or Web pages (McMillan 2000), we proceeded by exploring the Web sites using top-down criteria to identify the information collected. First, the pwc.com, deloitte.com, kpmg.com, and ey.com Web sites designated as "Global" on the home page were visited, and the following Web path was tracked: Main "Services" Web page-designated as "Services," "Our Services," or "What we do" > "Legal" services or "Law" Services. Moreover, where the key words "legal" or "law" did not appear on the main services Web pages, all other links shown as hypertexts were visited in search of the abovementioned key words.

Second, to survey the information related to the local business and operations of the networks' member firms, all individual countries, regions, and geographical clusters, accessible through the "Locations" site selector on each one of the Big Four home pages labeled "Global" were visited-a total of 151 PwC location sites, 123 Deloitte location sites, 102 KPMG location sites, and 115 EY location sites. The same process described above for the analysis of legal practices at a global level was followed with regard to each one of the visited sites.

Third, a general search on Google using the brand names of the Big Four plus the keywords "legal" and "law" was also conducted, allowing for the identification of a limited number of law firm corporate Web sites, which, despite not being accessible through a Big Four Web site, nevertheless were self-described as affiliated to, associated with, or a strategic partner of one of the Big Four. Fourth, archival material from the legal, accountancy, and economic press, accessible on the Internet, was compiled regarding the Big Four legal practices post-SOX. Finally, the global Web sites of PwC, Deloitte, KPMG, and EY were revisited in November 2015, following the same process as in March 2012.

As the data underscore, our research methodology uncovered a wealth of information about how the Big Four have presented their legal networks in the years since SOX (see Appendix 1). What this kind of study cannot tell us, however, is whether what the Big Four say about their legal networks is in fact true. We therefore make no representation, for example, about whether the legal services that the Big Four claim to offer in any particular legal market are, in fact, being delivered, or whether their legal work is of high quality. Nevertheless, given the data we report about what the Big Four are saying about the rapid growth in the size, sophistication, and geographic scope of their legal networks - and about the monetary and human resources they are devoting to building this capability—it would be surprising if what these large and sophisticated players are presenting on their Web sites does not bear some important connection to reality. Indeed, as we indicate below, the Big Four's practices have now been recognized by major ranking services such as Chambers and Partners, The Legal 500, Best Lawyers, IFRL1000, MergerMarket, Juve, Finyear, Expansión, Legal Community, Kommersant.ru, and the Financial Times as being among the best in certain markets and legal practices (for a sample of the countries where the Big Four were 
TABLE 1.

Countries Where the Big Four Promote Legal Services by Range of the Legal Services on Offer and Network (March 2012)

\begin{tabular}{lcccr}
\hline Range of Legal Services & $\begin{array}{c}\text { PwC } \\
\%\end{array}$ & $\begin{array}{c}\text { Deloitte } \\
\%\end{array}$ & $\begin{array}{c}\text { KPMG } \\
\%\end{array}$ & $\begin{array}{c}\text { EY } \\
\%\end{array}$ \\
\hline FLPs & 56 & 51 & 53 & 79 \\
NLPs & 44 & 49 & 47 & 21 \\
Total countries & 100 & 100 & 100 & 100 \\
& $(124)$ & $(97)$ & $(73)$ & $(29)$ \\
\hline
\end{tabular}

Note: Figures in parentheses are the base Ns of the percentages above.

ranked in 2011, see Appendix 1). At a minimum, the Web presence we document reveals the Big Four's ambitions for their legal services arms-as well as what they think will appeal to potential clients.

\section{The Reemergence of the Big Four in Law}

The rich data collected in our study reveal three major trends that have allowed the Big Four to reemerge as major players in the market for legal services: (1) the rebuilding, expansion, and diversification of their practice expertise beyond tax law, and their regional coverage beyond Europe; (2) the structuring of legal practices through the most highly integrated form of MDP in order to enhance the provision of truly integrated legal services and innovative business solutions; and, emboldened by the success of these moves, (3) the increasing global visibility given to their expertise in law.

\section{Practice and Regional Expansion and Diversification}

As shown in Table 1, in the spring of 2012, PwC was promoting legal services in 124 countries worldwide, Deloitte in ninety-seven countries, KPMG in seventy-three countries, and EY in twenty-nine countries. More importantly, the Big Four claimed to be offering a wide range of legal services in a majority of these countries. Thus, while the Big Four legal practices are known particularly for the provision of tax law, their selfpresentations on the Web suggest a commitment to expand into the transactional-led legal services market - and to do so in a way that addresses the growing need by multinational businesses for multidisciplinary business solutions across a global network. For example, Landwell \& Associés Société d'Avocats' ${ }^{2}$ Web page titled "Your challenges/our skills" implicitly distinguishes itself from traditional law firms by promising to provide "multidisciplinary solutions to address your challenges" (Landwell 2013). This offer is said to be supported by a network that brings together around 34,000 specialists in tax, business, and employment law in more than 150 countries, as well as by highly qualified industry-specific teams worldwide. As the Web site trumpets, jointly these resources allow

2. In 2015, Landwell \& Associés Société d'Avocats was rebranded PwC Société d'Advocats (PwC 2015b). 
TABLE 2.

Share of FLPs by Region and Network (March 2012)

\begin{tabular}{lccccc}
\hline Region & $\begin{array}{c}\text { PwC } \\
\%\end{array}$ & $\begin{array}{c}\text { Deloitte } \\
\%\end{array}$ & $\begin{array}{c}\text { KPMG } \\
\%\end{array}$ & $\begin{array}{c}\text { EY } \\
\%\end{array}$ & $\begin{array}{c}\text { Average } \\
\%\end{array}$ \\
\hline Europe & 46 & 63 & 67 & 91 & 61 \\
Americas & 26 & 29 & 21 & 9 & 23 \\
Africa \& Middle East & 17 & 8 & 10 & 0 & 11 \\
Asia Pacific & 11 & 0 & 3 & 0 & 5 \\
Total countries & 100 & 100 & 100 & 100 & 100 \\
& $(70)$ & $(49)$ & $(39)$ & $(23)$ & $(45)$ \\
\hline
\end{tabular}

Note: Figures in parentheses are the base Ns of the percentages above.

for the provision of solutions that are not just multidisciplinary, but that are also tailored for each client's business, and are provided in the most effective and efficient way. Hereinafter, we refer to countries where the Big Four make such claims as "full legal practices" or FLPs. Those countries where there was not a wide range of legal services shown on a Big Four corporate Web site yet there was still some reference to the provision of legal services (other than tax) are referred to as having a "nascent legal practice" or NLP. ${ }^{3}$

Table 2 also underscores a trend toward the geographic expansion and regional diversification of these practices into the emerging markets. By March 2012, PwC, Deloitte, and KPMG had all established legal practices in a significant number of countries in Central and South America, and Africa-including in many countries where global law firms were just beginning to establish offices (Harris 2011). Moreover, PwC was leading the expansion into Asia-Pacific. As an illustration of the reputation achieved by some of these practices over the years, Chambers $\mathcal{E}$ Partners (2011) describes PwC Laos as a first-tier firm for "General Business Law" that offers "a full-service transactional practice that is particularly known for its corporate, M\&A and IP work."

This trend toward global expansion is even more evident when one includes those NLP countries where there is only some reference to the provision of legal services shown on a Big Four corporate Web site. As Table 3 and Appendix 1 indicate, the vast majority of NLPs were identified in the emerging economies of Africa, Asia-Pacific, Eastern Europe, and Latin America. Indeed, in 2009, when PwC hired a former DLA Piper UK partner to establish PricewaterhouseCoopers Legal Middle East LLP (Lind 2010), the move was described on the network's

3. Because the Big Four have differing approaches to the marketing of their NLPs on the Web, the criteria by which certain countries have been included as having NLPs also differ by network: (1) PwC's NLPs indicate countries showing exclusively an immigration law contact or an explicit legal services contact on its Global Legal Services Network Web site (i.e., Portugal and Jamaica); (2) Deloitte's NLPs indicate countries where a standard set of law advisory services-Acquisition, divestiture, joint venture; legal purchaser and vendor due diligence; legal framework of supply chain management and distribution network; and statutory compliance-are accessible exclusively through a "Global Business Tax" hypertext (i.e., Deloitte Lebanon); KPMG's NLPs indicate countries included in a regional FLP, which otherwise are not visible on a local KPMG Web site (i.e., although legal services did not appear on the KPMG Hungary Web site, this country was nevertheless included in the KPMG Central and Eastern Europe Web site, which in turn showed a regional FLP); EY's NLPs indicate countries showing an explicit legal services contact in the EY “2011 Worldwide Corporate Tax Guide” (i.e., Chile). 
TABLE 3.

Share of NLPs by Region and Network (March 2012)

\begin{tabular}{lccccc}
\hline Region & $\begin{array}{c}\text { PwC } \\
\%\end{array}$ & $\begin{array}{c}\text { Deloitte } \\
\%\end{array}$ & $\begin{array}{c}\text { KPMG } \\
\%\end{array}$ & $\begin{array}{c}\text { EY } \\
\%\end{array}$ & $\begin{array}{c}\text { Average } \\
\%\end{array}$ \\
\hline Europe & 24 & 19 & 21 & 0 & 20 \\
Americas & 9 & 17 & 0 & 67 & 12 \\
Africa \& Middle East & 41 & 50 & 76 & 33 & 52 \\
Asia Pacific & 26 & 15 & 3 & 0 & 15 \\
Total countries & 100 & 100 & 100 & 100 & 100 \\
& $(54)$ & $(48)$ & $(34)$ & $(6)$ & $(36)$ \\
\hline
\end{tabular}

Note: Figures in parentheses are the base Ns of the percentages above.

TABLE 4.

Share of FLPs by Type of Firm and Network (March 2012)

\begin{tabular}{lccccc}
\hline Type of Firm & $\begin{array}{c}\text { PwC } \\
\%\end{array}$ & $\begin{array}{c}\text { Deloitte } \\
\%\end{array}$ & $\begin{array}{c}\text { KPMG } \\
\%\end{array}$ & $\begin{array}{c}\text { EY } \\
\%\end{array}$ & $\begin{array}{c}\text { Average } \\
\%\end{array}$ \\
\hline MDP & 56 & 65 & 59 & 39 & 57 \\
Legal services firm & 44 & 35 & 41 & 61 & 43 \\
Total countries & 100 & 100 & 100 & 100 & 100 \\
& $(70)$ & $(49)$ & $(39)$ & $(23)$ & $(45)$ \\
\hline
\end{tabular}

Note: Figures in parentheses are the base Ns of the percentages above.

global Web site as "the first of many new offices we intend to open across the Middle East, North Africa and South Asia” (PwC 2011).

\section{Integration}

As indicated in Section II (Historical Background), the Big Four were already trying to expand their legal networks in the 1990s. However, in direct contrast with the growth strategy embraced in the decade prior to SOX, which emphasized the separation of the accountancy and legal practices, by 2012 each of the Big Four had moved significantly toward integrating its legal practices within its MDP structure. As Table 4 illustrates, as of March 2012 three of the Big Four-PwC (56 percent), Deloitte (65 percent), and KPMG (59 percent)—showed a majority of their FLPs on the Web with no mention of any particular freestanding law firm or legal services firm as providing these services, with EY close behind at 39 percent.

Indeed, only in a small percentage of any of the Big Four's FLPs was access to the legal function operated through an independent Web site that was neither mentioned on nor linked to a Big Four institutional corporate Web site (see "Independent law firm only" in Table 5). Even in these instances, however, there was often a clear aim to integrate these practices into the relevant Big Four's overall service offerings. For example, while no reference was found to the provision of legal services in the EY Netherlands Web site, the Dutch law firm Holland van Gijzen Attorneys at Law \& Civil Law Notaries (HVG) explicitly claimed on its 
TABLE 5.

Share of FLPs by Web Path to Access Legal Services and Network (March 2012)

\begin{tabular}{lrrrrr}
\hline Web Path & $\begin{array}{c}\text { PwC } \\
\%\end{array}$ & $\begin{array}{c}\text { Deloitte } \\
\%\end{array}$ & $\begin{array}{c}\text { KPMG } \\
\%\end{array}$ & $\begin{array}{r}\text { EY } \\
\%\end{array}$ & $\begin{array}{c}\text { Average } \\
\%\end{array}$ \\
\hline Independent law firm Web site only & & & & & \\
Total law firm & 0 & 8 & 10 & 22 & 7 \\
& $(0)$ & $(4)$ & $(4)$ & $(5)$ & \\
Individual country Big Four Web site & & & & & \\
Services > Legal/Law & 27 & 41 & 13 & 0 & 24 \\
Services > Tax \& legal/Tax & 44 & 49 & 72 & 65 & 54 \\
Services > Other services & 0 & 2 & 5 & 13 & 3 \\
Total individual country & 71 & 92 & 90 & 78 & \\
& $(50)$ & $(45)$ & $(35)$ & $(18)$ & \\
Global Big Four Web site only & & & & & \\
Services > Legal & 29 & 0 & 0 & 0 & 11 \\
Total global & 29 & 0 & 0 & 0 & \\
Total countries* & $(20)$ & $(0)$ & $(0)$ & $(0)$ & \\
& 100 & 100 & 100 & 100 & 100 \\
& $(70)$ & $(49)$ & $(39)$ & $(23)$ & \\
\hline
\end{tabular}

*Total countries $=$ Sum of total law firm, total individual country, and total global.

Note: Figures in parentheses are the base Ns of the percentages above.

Web page that a key strength of the firm is "our alliance with Ernst \& Young Tax Advisors" (HVG 2012). Moreover, the integration of the services provided by this independent law firm within the business of EY was also apparent by the unmistakable EY brand image on the law firm's Web site, as well as by the fact that HVG was included in the EY Netherland Integrated Annual Review 2011/2012 (EY 2012c).

\section{Visibility}

Although the expansion and diversification of the Big Four legal networks between 2002 and 2012 belied the common perception that the accountancy giants had abandoned their ambitions to become important players in the global legal services market, the extent of these networks was not readily apparent from the Big Four's main Web sites. Thus, in 2012 the global Web sites of three of the Big Four-Deloitte (2012b), KPMG (2012b), and EY (2012a)_did not mention the countries in which their member firms provided legal services to clients (we return to PwC's strategy below). Instead, as Table 5 indicates, legal services were accessible mostly on individual-country-level Web sites and integrated with the tax function. Moreover, while some of these country sites listed legal services as a core service line under the heading of "Legal" or "Law," in most cases, access to legal services came through the tax function. Indeed, according to our study, an average of 54 percent of all Big Four FLPs were only accessible through a "Tax \& Legal" or "Tax" core service line. 
Although our analysis of the Web sites in question cannot determine why the Big Four have chosen to take the local and subject-matter-driven approach, two explanations seem plausible. The first is entirely prudential. Given the regulatory and public relations issues that continued to hang over the Big Four's entry into the market for legal services in 2012, it is quite likely that the leaders of these international networks were still advocating for a cautious global strategy regarding their member firms' legal businesses. Supporting this argument, we found no reference to the provision of legal services in any of the Big Four's Global Annual Reviews for the years 2011 and 2012.

In addition to being prudent, however, attaching legal services to the tax function also allowed the Big Four to leverage their strong brands in this area and to take advantage of the growing desire by many corporate clients for an integrated approach to tax and legal services. $\mathrm{PwC}$ member firms, for example, ranked in the first tier in forty-two of fifty countries analyzed in the comprehensive guide to the world's leading tax firms World Tax (2011) — a tier in which PwC competes with the other Big Four tax and legal networks as well as top US law firms such as Cleary Gottlieb Steen \& Hamilton, Davis Polk \& Wardwell, Skadden, Arps, Slate, Meagher \& Flom, Sullivan \& Cromwell, and Wachtell, Lipton, Rosen \& Katz, and leading UK law firms such as Allen \& Overy, Clifford Chance, Freshfields Bruckhaus Deringer, Linklaters, and Slaughter and May. As a respondent to the prestigious survey that Asian Legal Business conducts of leading tax law firms makes clear, this kind of integration of tax and legal services is what many top clients are increasingly demanding: "on the big deals you need lawyers with corporate grounding providing tax advice ... ideally, one would like to have the lawyers and the accounting firms in the same room, working together" (ALB 2010). By making their legal services offering visible through the tax function, the Big Four underscored that they could go one step better by putting lawyers and accountants in the same firm.

Although both discretion and a desire to leverage their leading tax brands helps explain why the Big Four tended to make their legal services offerings visible primarily through their local and tax Web sites, by the spring of 2012, PwC was already beginning to take a bolder and more ambitious approach. Unlike the others, $\mathrm{PwC}$ features a main legal service line as a hypertext integrated within the collection of PwC global services, and linked to a "PwC Global Legal Services Network" (GLSN) Web site (PwC 2012a, 2012b). This GLSN site illustrated that the network was engaged in a full range of business-related legal services, resembling those typically promoted by a business law firm. At the same time, the site also highlighted a global, multidisciplinary, and solution-oriented approach as the network's main source of differentiation from traditional law firms.

Moreover, by 2012, PwC's GLSN Web site gave access to the list of countries where legal services were on offer by $\mathrm{PwC}$, including twenty full-scale legal practices-representing 29 percent of PwC's FLPs_-which otherwise where not visible at the individual-country-level PwC Web site (see "Global Big Four Web site only" in Table 5). India represents an interesting example. Although the PwC's India country Web site did not promote legal services, India's "Country Profile," accessible through PwC's GLSN, did display the following statement and accompanying legal 
practices: "PwC India's team of lawyers and corporate law professionals work in tandem with advisory and Tax specialists in providing solutions to clients' business issues.... Corporate $\&$ commercial structuring, Mergers \& acquisitions, Information technology, Commercial contracts, Competition law, Immigration, Employment law, Legal entity risk assessment, Legal entity maintenance, Corporate secretarial, Banking and finance, [and] Documentation and support" (PwC 2012b). Although discretion may have played a role here as well-India, after all, bars virtually all foreign law firms from practicing in the country (Wilkins and Papa 2013) - the visibility that PwC gave to its legal services offerings in India on its GLSN site underscores its desire to signal that its legal network is fully integrated into its broader set of global services offerings.

It is not surprising that $\mathrm{PwC}$ was more aggressive in staking this claim in 2012 than were its rivals. PwC's legal network Landwell was the only accountancy-tied law firm network to survive SOX. Indeed, as of March 2012 Landwell was still accessible through its own site on the Internet (http://www.landwellglobal.com/), which showed law firms operating in five European countries. Unlike in 2003, when PwC sought to portray Landwell as an independent network (Landwell 2003), however, by 2012, Landwell's law firms had already been integrated into PwC's international network. This strategy proved quite successful. By 2014, PwC reported that its "global legal business has delivered substantial double-digit revenue growth since 2007" (PwC 2014). Not surprisingly, these results did not escape the attention of the remaining three members of the Big Four.

\section{Coming Out of the Shadows (2013-2015)}

When we revisited the Big Four's Web sites in 2015, it was clear that all three trends identified above had accelerated during the intervening three years. By June 2015, Deloitte, EY, and KPMG had all joined PwC in giving global visibility to their extensive legal expertise in all areas of business-related law. ${ }^{4}$ By 2012, Deloitte was already marketing a core global "Legal" services line on its global Web siteDeloitte Legal-with the illustrative logo "representing tomorrow" (Deloitte 2013b). During the first quarter of 2014, EY's global Web site was also featuring a

4. On November 11, 2015, PwC's Global Legal Services offering included employment, entity governance and compliance, immigration, international business reorganizations, M\&A, antitrust and EU competition, banking and finance, commercial litigation, cyber security and data protection, energy law, financial services regulation, information technology, intellectual property, private client, public law, real estate, tax litigation, and white-collar corporate crime (PwC 2015a); Deloitte's Legal Web site showed the following legal services: commercial law solutions, corporate and mergers and acquisitions solutions, employment and pension solutions, and tax controversy solutions (Deloitte 2015b); KPMG's Global Legal Services Web site disclosed the following practice groups: commercial and corporate law, M\&A and reorganizations, employment law, financial services, building, construction, and real estate, antitrust and merger control, intellectual property, media and technology, corporate recovery, litigation, arbitration and alternative dispute resolution, energy and natural resources, public sector, family-owned businesses and private clients, and risk and compliance (KPMG 2015a); and EY's legal services offering on its global corporate Web site included corporate and commercial, labor and employment, $M \& A$ and transaction, financial services, IP/IT, insolvency and restructuring, real estate, distribution and franchising, corporate reorganizations and project management, and global immigration (EY 2015b). 
TABLE 6.

Share of FLPs by Region and Network (November 2015)

\begin{tabular}{lrrrrr}
\hline Region & $\begin{array}{c}\text { PwC } \\
\%\end{array}$ & $\begin{array}{c}\text { Deloitte } \\
\%\end{array}$ & $\begin{array}{c}\text { KPMG } \\
\%\end{array}$ & $\begin{array}{c}\text { EY } \\
\%\end{array}$ & $\begin{array}{c}\text { Average } \\
\%\end{array}$ \\
\hline Europe & 45 & 49 & 64 & 51 & 51 \\
Americas & 22 & 23 & 23 & 14 & 21 \\
Africa \& Middle East & 21 & 19 & 6 & 20 & 17 \\
Asia Pacific & 12 & 9 & 8 & 14 & 11 \\
Total & 100 & 100 & 100 & 100 & 100 \\
& $(85)$ & $(69)$ & $(53)$ & $(69)$ & $(69)$ \\
Change in total FLPs in 2015 from 2012 & 21 & 41 & 36 & 200 & \\
& $(15)$ & $(20)$ & $(14)$ & $(46)$ & \\
\hline
\end{tabular}

Note: Figures in parentheses are the base Ns of the percentages above.

Law practice- "Law: Passion for excellence across the globe"-integrated within the "tax" core service line (EY 2015b). Similarly, during the summer of 2015, a KPMG "Global Legal Services" hypertext appeared, complementing the list of practices on the network's "Global Tax" core service line (KPMG 2015a).

Similarly, revisiting the global Web sites of the Big Four in November 2015 also confirmed the remarkable international expansion and regional diversification of these networks into emerging markets (see Table 6). Most notably, since March 2012, EY has increased 200 percent the number of countries where its member firms offer FLP, shifting from the almost exclusive location of FLPs in Europe (see Table 2) to having 20 percent of its FLPs in Africa and the Middle East, and 14 percent in Asia-Pacific.

The development of this expansionist scheme is consistent with the Big Four's global strategy to be "undisputed leaders in professional services" (Deloitte 2015a). Thereby, since 2012, the Big Four have continued to bolster their legal practices through what The Australian Business Review (2014) describes as a "cherry-picking of top-end lawyers and their legal teams." Consider, for instance, Richard Norbruis, Global People Partner of Freshfields Bruckhaus Deringer, who in 2014 was appointed a member of EY's Global Law Leadership Team and Global Transaction Law leader, focusing on building, strengthening, and managing the network's legal practice worldwide (EY 2014). In 2015, another Freshfields partner, Nikolaus Schrader, joined PwC Legal Germany to colead the nationwide corporate and M\&A practice group (Juve 2015). The aim by $\mathrm{PwC}$ to "spearhead growth in legal services" is also exemplified by the hiring of Tony O'Malley, former King \& Wood Mallesons' Deputy Global Managing Partner, to lead PwC's legal practice in Australia and across Asia-Pacific (PwC 2014; Whealing 2014). Similarly, DLA Piper's joint head of the Asia-Pacific Corporate practice, David Morris, was hired by KPMG in Australia (KPMG 2015b) to lead and develop its legal practice beyond its traditional tax law practice in that region.

Nonetheless, despite these and other examples of lateral hiring to expand and upgrade their legal expertise, it is important to note that the leaders of the Big Four's legal teams are primarily individuals who have spent the majority of their careers inside one of these institutions. This is most evident with regard to their "global legal 
services leaders": EY's Cornellius Grossman, PwC's Leon Flavell, Deloitte's Piet Hein Meeter, and KPMG's Manfred Kessler-all have come from long careers in Big Four member firms. This approach provides another important insight into their current strategy. In the 1990s, the Big Four went to great lengths to present the lawyers working in their legal networks as independent professionals who were insulated from the rest of the firm. By 2015, the strategy was to emphasize that lawyers, like all the other professionals working in their MDP structure, are fully integrated into the culture of the Big Four, thus enhancing their ability "to provide holistic guidance around strategic business decisions” (Deloitte 2015b; EY 2015b)

Finally, since 2012 the Big Four have also embraced new opportunities to integrate their legal practices into their existing global networks. For instance, during the course of our study, Deloitte initiated the process to integrate its German strategic partner Raupach \& Wollert-Elmendorff Rechtsanwaltsgesellschaft mbH fully into the Deloitte network-now rebranded Deloitte Legal Rechtsanwaltsgesellschaft mbH (AHK 2015; Deloitte 2015a), and to rebrand its Canadian-affiliated law firm Heddema \& Partners LLP as Deloitte Tax Law LLP (Deloitte 2012a). Similarly, KPMG Law LLP has integrated the tax law firm Moskowitz \& Meredith LLP and the leading global immigration law firm Greenberg Turner (KPMG 2012a, 2012c). In each instance, the goal is to show, in the words of a Deloitte professional, that legal services are "deeply integrated with one of the world's leading accounting firms” (Deloitte 2012a).

The biggest change to occur since 2012, however, harkens back to the move that first signaled the original emergence of the Big Four in the market for legal services-the reemergence of three of the Big Four as major players in the UK market for legal services. This time, however, the accounting giants are doing so with the full blessing of the regulators. Pursuant to the UK 2007 Legal Services Act (discussed more fully below), since 2014, Ernst \& Young LLP (EY), KPMG LLP (KPMG), and PricewaterhouseCoopers LLP ( $\mathrm{PwC}$ ) have applied for-and have been granted-licenses to operate multidisciplinary practices regulated by the Solicitors Regulation Authority (SRA 2014a, 2014b, 2016). As a result, these professional services firms may now integrate the kind of legal services that previously could be offered only by entities solely owned and controlled by lawyers into their UK businesses. Following the lead, Deloitte's legal leader, Piet Hein Meeter, told Dowell (2014) that "the UK is definitely on the list."

Clearly, more than a decade after they were proclaimed dead by most pundits, by 2015 the Big Four's increasingly integrated and expansive legal networks are not only alive and well in the global market for legal services, but they have also come out of the shadows to promote their fully integrated model for delivering multidisciplinary professional services in many of the most important legal markets in the world. In the next section, we examine how they have managed to achieve this remarkable feat.

\section{HOW DID THIS HAPPEN?}

Looking back, we believe that four interrelated factors have allowed the Big Four accounting firms to expand their legal offerings: (1) gaps in the regulation of 
auditor independence, (2) changes in the regulatory framework of the legal profession, (3) globalization-and the attractiveness of the global market for legal services, and (4) the organizational evolution of the Big Four. Significantly, each of these developments appears likely to continue in the coming years, thereby accelerating the growth and importance of the Big Four's legal networks.

\section{Gaps in the Regulation of Auditor Independence}

The enactment of SOX in the United States and other similar laws around the world banning auditor-provided legal services to listed audit clients represented such a blow for the large accountancy firms' multidisciplinary model that initially it was difficult to read beyond the letter of the law. However, gaps in auditor independence regulation have allowed the Big Four to rebuild their nonaudit businesses, including legal services, in many countries around the world-even in the United States.

Contrary to popular perception, Section 201 of SOX did not establish an audit-firm-only rule. Instead, it provided a list of nonaudit services (NASs) that were off-limits for registered public accounting firms regarding their US-listed audit clients, empowering audit committees of listed companies to preapprove the purchase of tax services and other "SOX-permissible" NASs from the auditor (Naiker, Sharma, and Sharma 2013, 298). This left SOX with what has been described as "an important gap in its reforms" (Barrett 2004, 5). As many prominent authors have argued, this US classification-based approach to auditor independence regulation gives a "false sense of precision" (Alles, Kogan, and Vasarhelyi 2005, 11), as neither the nine categories of prohibited nonaudit services nor the SOX-admissible nonaudit services are clear-cut.

Given the difficulty in defining where auditing ends and consulting begins, there has been considerable inconsistency in how audit committees have responded to their preapproval responsibility, and "very few sanctions" for independence violations based on auditors delivering prohibited NASs have been reported (McKenna 2011). As a result, accountants have been able to continue to provide publicly traded US audit clients with a wide range of advisory services in which the fields of accounting, consulting, and law overlap, such as risk and compliance, financial management, human resource organization, forensics, and merger due-diligence services (Schmidt 2012). Most importantly, the Big Four have continued to provide their audit clients with critical, high-end tax services (Barrett 2004; Paton 2006), a space where, as we indicated at the outset, the accountancy firms have always competed aggressively with top national and global law firms.

Although gaps in the regulatory framework and its enforcement have allowed the Big Four to continue to deliver the abovementioned law-related services to their audit clients, the real growth in the development of each of the Big Four's legal networks has come from their ability to sell legal services to the vast majority of companies around the world that are not their audit clients. Nothing in SOX prohibits this practice. As a result, as Gwilliam, Teng, and Marnet (2014, 8-9) demonstrate, "since the divestment at the start of the new millennium, the very 
large firms have rebuilt their consulting and other activities beyond audit to levels of fee income on a par in relative terms to those before the divestment (and in absolute terms significantly higher). However, the engine of this growth has entirely been NAS provided to clients other than audit clients."

The regulatory situation in Europe has been even more accommodating. Although the European Commission followed the United States in adopting rules that purported to prevent audit firms from providing NAS to their audit clients, the actual implementation of this directive varied widely among member states. As a result, "the provision of NAS by auditors to the companies they audit remains commonplace" (European Commission 2011, 15). Even in member states such as France where "there is a ban on the provision of NAS from any member of the auditor's network to any member of the audited company's group" (European Commission 2011, 15), existing regulation still has not prevented the Big Four from providing a wide range of legal services through law firms affiliated to the international networks. Taj Société d'Advocats rejoining Deloitte's international network is a case in point. As Deloitte France's CEO Jean-Paul Picard made clear, this affiliation would "enable the firm to provide specific services to [Deloitte's] auditing clients and to develop its services to non-audit clients in synergy with the Deloitte network [and] in accordance with the rules" (Collins 2006). The fact that Deloitte's French CEO had no qualms about making such a statement publicly underscores just how little he believed that France's regulation was likely to constrain Deloitte's attempt to integrate Taj's legal service offerings into Deloitte's multidisciplinary offerings.

Even new and more stringent rules on auditor independence adopted after the 2008 financial crisis have failed to close these gaps fully (Ratzinger-Sakel and Schönberger 2015). In April 2014, the European Parliament and the Council passed Directive 2014/56/EU amending Directive 2006/43/EC to impose even more restrictions on the Big Four's ability to provide NASs when also conducting statutory audits of annual accounts and consolidated accounts. These supranational restrictions have now established a cap on the amount of nonaudit fees that the auditor may receive, as well as a list of prohibited services that the auditor is not permitted to provide, which notably includes certain tax services. While it remains unclear how these rules are to be applied by the different member states of the European Union, similar rules at the national level in France, Germany, and the United Kingdom have not prevented the revival of the Big Four legal practices in these three important European countries (Esteban Ferrer and Wilkins 2013). These gaps in the regulation of auditors have been greatly accentuated by changes in the regulation of the legal profession.

\section{Changes in the Regulatory Framework of the Legal Professions}

During the last decade of the twentieth century, a growing chorus of critics raised concerns that the regulatory framework governing professional services in general-and legal services in particular-restricted competition more than was appropriate or necessary, resulting in higher prices and decreased competition, and 
limiting innovation and job growth in this important economic sector (OECD 2000, 7; Terry 2008; Flood 2011; Quak and Shüßler 2015). In June 1999, the OECD's Committee on Competition submitted a report advocating reducing the regulation of many professional services. This report ushered in a trend toward government intervention to deregulate the market for legal services. This deregulation has taken three forms, all of which have eased the entry of the Big Four into the global legal services market: (1) the creation of alternative business structures (ABSs) that allow lawyers and nonlawyers to go into business together in fully integrated multidisciplinary practices, and nonlawyers to invest in and manage law firms, (2) the reduction of activities that are exclusively reserved for licensed lawyers, and (3) a shift in the control of the professions from professional associations to independent regulators (OECD 2000).

The United Kingdom has been the most aggressive of the OECD jurisdictions in taking up this deregulatory crusade. Following Australia's lead, the United Kingdom enacted the Legal Services Act of 2007 (LSA), implementing the most influential deregulatory reforms in the history of the market for legal services anywhere in the world. Particularly, these reforms opened the legal services sector in the United Kingdom to the creation of the type of ABSs described above. According to the Institute of Chartered Accountants in England and Wales (ICAEW 2015), by becoming an ABS, an accounting firm is authorized to integrate the following legal services with the "usual suite of services permissible within an accountancy practice": (1) "whichever reserved legal services the ABS is expressly licensed to provide" by a licensing authority such as the SRA-namely, the conduct of litigation, the exercising of rights of audience, reserved instrument activities (such as conveyancing), probate activities, and/or the administration of oath; and (2) all nonreserved legal services, such as general legal advice, transactional corporate advice, and employment advice, which "when provided by a lawyer, or under their supervision, these services will attract legal advice privilege." As indicated above, PwC, KPMG, and EY have each applied for and received ABS status to operate as fully integrated MDPs, thereby increasing their ability to "embed legal advice" into their businesses (PwC 2016).

Nor is the United Kingdom alone in following this path. In addition to Australia, where ABSs and MDPs have long been legal, several other countries are actively considering adopting similar reforms, including major legal markets such as Canada, South Korea, Singapore, and Hong Kong. Even in the United States, the American Bar Association's 2020 Commission on the future of professional regulation actively debated allowing MDPs for the first time since the House of Delegates rejected a similar recommendation in 2001. Although the proposal was ultimately defeated, the fact that it received serious consideration underscores just how far the deregulatory trend has moved in the last several years.

At the same time, the Big Four have been able to exploit regulatory loopholes in important jurisdictions where the regulation of the legal profession is less developed. Consider, for example, China. Although "foreign law firms are explicitly barred from directly or indirectly investing in, managing, operating, controlling or taking equity interests in Chinese law firms," there is a legal gap with regard to accountancy firms (Zhang 2014). As Andrew Godwin, Associate Director of the Centre for Asian Law at Melbourne Law School and a former partner with 
Linklaters in Shanghai, reported to Zhang (2014): "[I am not aware of] regulations expressly restricting the form or nature of cooperation between a Chinese law firm and an international accounting firm ... [although] there are no regulations expressly permitting such cooperation." Taking advantage of this regulatory ambiguity, Deloitte China markets the provision of legal services through Qin Li Law Firm, "a licensed Chinese law firm that specializes in cross border legal advisory services" as part of the international Deloitte network (Deloitte 2014b). Taken together, the trend toward deregulation in many advanced economies and the regulatory gaps in many emerging ones have made it easier for the Big Four to expand their legal services offerings. Trends in the transnational regulation of professional services appear likely to pave the way for even further expansion.

Whatever national governments and bar associations might like to decide, there is significant pressure building for the deregulation of professional services at the transnational level through the General Agreement on Trade in Services. Not surprisingly, the large accountancy networks have played a key role in these debates. Specifically, the Big Four have actively lobbied to eliminate global barriers to trade and investment in professional services, including services beyond the accountancy profession (Arnold 2005; Suddaby, Cooper, and Greenwood 2007). Ironically, big law firms have also taken up the global deregulatory call. Although constitutionally mistrustful of government intervention, many large law firms have nevertheless not been shy about asking governments to assist them in loosening various aspects of professional regulation that are seen as restricting their ability to expand geographically and generate higher profits. Thus, large law firms have become agents of deregulation at international and national forums, urging the easing of restrictions on conflicts of interest, the entry of foreign law firms into domestic legal markets, the hiring and compensation of nonlawyer professionals, the acceptance of outside capital, and the creation of new structures and practices such as Swiss vereins (Flood 2011; Loughrey 2011; Richmond and Corbin 2014).

The fact that these regulatory trends have occurred in the context of a legal services market that has become increasingly globalized-with a growing percentage of that global activity located in the emerging economies in Asia, Latin America, and Africa-has further facilitated the Big Four's reemergence in the legal field in the years since 2002 .

\section{Globalization and the Size of the Legal Market}

As indicated in Section II (Historical Background), the Big Four have always been attracted by the size and profitability of the legal market relative to the decline in their core audit business. The overall growth in the size of the legal market since 2002 has only exacerbated this disparity. According to published estimates, between 2005 and 2014 the global legal services market grew by 72 percent-including a 6 percent increase since the financial crisis of 2008-reaching a total value of around $\$ 618$ billion (Datamonitor 2006; World Trade Organization 2010; MarketLine 2015; TheCityUK 2016, 6; Statista 2017). This amount represents three times the value of the audit market, according to data from MarketLine 
(2014). Moreover, the legal services market is incredibly fragmented. While the Big Four's joint turnover for audits in 2014 represents 23 percent of the value of global audits, the turnover jointly generated by all the top law firms ranked in the Am Law 100 for the same year (American Lawyer 2015) accounted for a scant 13 percent of the global legal market. In this context, if any of the Big Four were to capture even a 1 percent share of the market's forecasted value of $\$ 726.2$ billion for 2019 (MarketLine 2014), that one network would become far and away the largest legal services organization in the world.

Moreover, when combined with the strong trend toward globalization, the legal services market's fragmentation has also furthered the Big Four's competitive position vis-à-vis traditional law firms. As the commentators who proclaimed the demise of the Big Four legal networks in the years following SOX accurately reported, large law firms have become significantly more global in recent years. Where these commentators erred, however, was in failing to understand that the increasing globalization of the legal services market would favor the model of international expansion pursued by the Big Four far more than the one followed by most law firms.

As multinational companies have rapidly expanded their operations around the globe, they have increasingly looked for professional service firms that can provide them with consistent services-including legal services-across their entire platform (Hitt et al. 2001, 2006; Morgan and Quack 2005). Given their extensive experience in marshaling global resources (Abdelzaher 2012), the Big Four are in an ideal position to meet this need. As indicated in Table 6, this is particularly true in the emerging economies of Asia-Pacific, Latin America, and Africa, which are likely to see the fastest growth in the demand for legal services.

A comparison with global law firms underscores just how big an advantage this is for the Big Four. Table 7 reports the global reach by region of Baker McKenzie and DLA Piper, widely considered to be two of the most global law firms in the

TABLE 7.

Share of Countries Covered by Baker McKenzie and DLA Piper, by Region and Type of Firm (September 2015)

\begin{tabular}{lcccccc}
\hline & $\begin{array}{c}\text { Baker } \\
\text { McKenz. } \\
\text { NF* } \\
\%\end{array}$ & $\begin{array}{c}\text { Baker } \\
\text { McKenz. } \\
\text { AF* } \\
\%\end{array}$ & $\begin{array}{c}\text { Baker } \\
\text { McKenz. } \\
\text { Total } \\
\%\end{array}$ & $\begin{array}{c}\text { DLA } \\
\text { Piper } \\
\text { NF* } \\
\%\end{array}$ & $\begin{array}{c}\text { DLA } \\
\text { Piper } \\
\text { RF* } \\
\%\end{array}$ & $\begin{array}{c}\text { DLA } \\
\text { Piper } \\
\text { Regal } \\
\%\end{array}$ \\
\hline Europe & 42 & 0 & 42 & 30 & 11 & 41 \\
Americas & 16 & 2 & 18 & 3.6 & 3.6 & 7 \\
Africa \& Middle East & 11 & 2 & 13 & 11 & 27 & 38 \\
Asia Pacific & 20 & 7 & 27 & 10.7 & 3.6 & 14 \\
Total countries & 89 & 11 & 100 & 55 & 45 & 100 \\
Change in total countries & $(40)$ & $(5)$ & $(45)$ & $(31)$ & $(25)$ & $(56)$ \\
$\quad$ covered in 2015 from 2012 & & & 10 & & & 30 \\
& & & $(4)$ & & & $(13)$
\end{tabular}

*NF stands for network firm; AF stands for associated firm (as referred to on Baker McKenzie's global corporate Web site); and RF stands for relationship firm (as referred to on DLA Piper's global corporate Web site).

Note: Figures in parentheses are the base Ns of the percentages above 
world. Just at the level of coverage, the forty-five and fifty-six countries covered by Baker McKenzie and DLA Piper, respectively, are significantly fewer than those covered by each of the Big Four legal networks (except for KPMG), with PwC covering almost twice as many countries (eighty-five) as Baker McKenzie. Moreover, given the Big Four's announced intentions, this disparity seems certain to grow, particularly in the emerging economies. Although Baker McKenzie and DLA Piper currently have significant presence in the Americas, Africa, and Asia, they will be hard pressed to match the investments the Big Four are making in their growth in these increasingly important regions.

Both PwC and EY have declared their intention to double their respective networks' legal headcounts in Asia (Broomhall 2014; Kriegler 2014). Indeed, EY has gone even further, declaring in 2011 that it intended to invest more than US\$1.5 billion over five years, "mainly in the emerging markets," and was planning to "maintain this investment at comparable levels for the foreseeable future" (EY 2011, 41). Although this investment was not specifically earmarked for legal services, the fact that EY is increasingly embedding these offerings in its broader multidisciplinary offerings means that its legal network will benefit from this significant investment.

This last point highlights a final important advantage that the Big Four have over law firms in pursuing a global strategy. Returning to Table 7, when one looks more closely at how Baker McKenzie and DLA Piper are covering the jurisdictions in their network, it is clear that many countries are being served by "associated" or "relationship" firms that have only contractual relationships with the main organization. This is particularly true for DLA Piper, where 45 percent of its fifty-six total offices fall under this category. Although the firm asserts that these "relationship firms" have adopted "various practices and procedures that are aligned with DLA Piper entities," it concedes that "they are not themselves part of or financially integrated with any DLA Piper entities" (DLA Piper 2017).

This concession is significant. As many commentators have noted, these affiliations or referrals raise important questions of quality control and coordination (Grady 2016). When compared to the trend noted in Table 4 of the Big Four moving to integrate law firms, with whom they only had a contractual association, into their global MDP networks, it is clear that the accountancy firms have an advantage in claiming to offer multinational companies integrated global service. Indeed, while most global law firms have increasingly embraced a federal model where local law firms are affiliated under the umbrella of a Swiss verein-often expressly modeled on the model adopted by the global accounting firms in the 1980s - the Big Four themselves have moved away from this structure in order to achieve greater integration of their multidisciplinary practices. This brings us to the final, and arguably the most significant, factor that has allowed the Big Four to rebuild their legal networks notwithstanding the concerted efforts by regulators to prevent them from doing so.

\section{Organizational Evolution}

The global legal services market grew at an unprecedented rate in the years following SOX. According to one estimate, between 2004 and 2008, demand for 
legal services expanded at a compound annual rate of 3.7 percent (Sarfo 2013). Although this rising tide lifted virtually all law firm boats, a relatively small group of elite law firms began to capture an increasingly large share of this global workand an even larger share of global profits (Aronson 2007; Segal-Horn and Dean 2011). They did so by rigorously focusing on "bet the company deals" and litigation for high-end financial clients, while "get[ting] rid of local clients" and small and medium-size enterprises (Faulconbridge and Muzio 2016, 110). The mantra was "premium work for premium clients," exiting commodity businesses to concentrate on high-margin work (Wilkins 2010, 2090). The 2008 global financial crisis further exacerbated this tendency, as law firms fought to hold on to premium work as a hedge against declining profits and departing partners (Wilkins 2015).

This strategy proved effective in differentiating the very top law firms from their rivals through quality and specialization (Mawdsley and Somaya 2015). However, it also led many firms - including many who were not in the very top tier, but felt compelled to try to be-to abandon a variety of practice areas such as employment, property, and general corporate law that had long been a part of the suite of services large law firms offered to their clients (Faulconbridge and Muzio 2016). As a result, many law firms began to lose key parts of the "industry expertise" (Juve 2012) that had given them credibility in the marketplace. This loss, in turn, opened the door for the Big Four, whose organizational model was evolving to emphasize precisely this kind of integration of law into business solutions.

Paraphrasing Hamel and Välikangas (2003), it has taken decades for the Big Four to elaborate the MDP idea into a robust operational model. Specifically, the "[f]inal consummation of the true global multidisciplinary practice, not just an affiliated network of service providers, await[ed] the breaking down of different practice patterns, norms and values, and the development of new interpretive schemes to which all professionals [could] commit" (Brock and Powell 2005, 465). Table 8 summarizes this process with respect to legal services by dividing the Big Four's efforts to elaborate their MDP model into five relatively distinct stages: (1) the nascent MDP model of the 1980s, when the Big Four first began providing legal services (as well as consulting services and IT) adjacent to their core audit and tax business, and began marketing themselves as MDPs; (2) a federal MDP model during the 1990s, when the Big Four developed global legal networks through the establishment of their own and affiliated or associated law firms staffed by star lawyers acquired from law firms; (3) a period of crisis and renewal immediately following SOX and the demise of Arthur Andersen, when the Big Four unwound their legal networks and retreated to providing a small range of auxiliary legal services in markets with less regulatory scrutiny; (4) a new integrated MDP model in the period from 2005-2011, when the Big Four took advantage of gaps in the regulatory framework and increasing demand by multinational clients to rebuild their global legal services networks as integrated FLPs; and (5) an emerging integrated solutions model in the period since 2012, where the Big Four now actively compete with law firms to provide clients with global business solutions at the intersection of law, business, strategy, technology, process management, and talent development. As EY's chairman and CEO James Turley stated in his farewell letter when he stepped down in 2012, the goal is to develop 
TABLE 8.

Chronology of the Organizational Evolution of the Elite Accounting Firms' Diversification into Law

\begin{tabular}{|c|c|c|c|c|}
\hline $1980 \mathrm{~s}$ & $1990 s-2000$ & 2001-2004 & 2005-2011 & $2012-$ \\
\hline $\begin{array}{l}\text { Stage 1: Nascent } \\
\text { MDP } \\
\text { Elite accounting } \\
\text { firms increase } \\
\text { the scope of } \\
\text { law-related } \\
\text { accounting } \\
\text { services, and } \\
\text { begin to pro- } \\
\text { vide general } \\
\text { corporate and } \\
\text { commercial } \\
\text { law advice in } \\
\text { certain } \\
\text { jurisdictions. } \\
\text { Increase in the } \\
\text { number of law- } \\
\text { yers employed } \\
\text { in-house by } \\
\text { elite account- } \\
\text { ing firms, } \\
\text { mostly for } \\
\text { non-client- } \\
\text { facing } \\
\text { positions. } \\
\text { Elite accounting } \\
\text { firms begin to } \\
\text { market them- } \\
\text { selves as global } \\
\text { MDPs, cross- } \\
\text { selling a diver- } \\
\text { sified portfolio } \\
\text { of services to } \\
\text { the audit func- } \\
\text { tion's interna- } \\
\text { tional client } \\
\text { base }\end{array}$ & $\begin{array}{l}\text { Stage 2: Federal } \\
\text { MDP } \\
\text { Regulatory } \\
\text { uncertainty } \\
\text { regarding the } \\
\text { status of } \\
\text { MDPs, particu- } \\
\text { larly in } \\
\text { Europe. } \\
\text { Elite accounting } \\
\text { firms begin to } \\
\text { establish law } \\
\text { firms and affili- } \\
\text { ate or associate } \\
\text { with existing } \\
\text { law firms, } \\
\text { eventually } \\
\text { integrating } \\
\text { them into sep- } \\
\text { arately branded } \\
\text { international } \\
\text { networks: } \\
\text { Andersen } \\
\text { Legal, Land- } \\
\text { well, KLegal, } \\
\text { and EY Law. } \\
\text { Legal becomes a } \\
\text { core function. } \\
\text { Appoint star } \\
\text { lawyers to lead } \\
\text { the interna- } \\
\text { tional legal } \\
\text { networks and } \\
\text { target lateral } \\
\text { hires from top } \\
\text { law firms. } \\
\text { Global marketing } \\
\text { campaign to } \\
\text { portray the } \\
\text { legal function } \\
\text { as a top inter- } \\
\text { national law } \\
\text { firm. }\end{array}$ & $\begin{array}{l}\text { Stage 3: Crisis } \\
\text { and renewal } \\
\text { Strong response } \\
\text { against MDPs } \\
\text { by the account- } \\
\text { ing and the } \\
\text { legal profes- } \\
\text { sions, particu- } \\
\text { larly in the } \\
\text { United States. } \\
\text { Financial scan- } \\
\text { dals, demise of } \\
\text { Arthur Ander- } \\
\text { sen, and enact- } \\
\text { ment of SOX. } \\
\text { Big Four take } \\
\text { steps to } \\
\text { unwind their } \\
\text { legal networks. } \\
\text { Support for the } \\
\text { surviving legal } \\
\text { practices is } \\
\text { transferred to } \\
\text { the networks' } \\
\text { national firms, } \\
\text { which mostly } \\
\text { retreat to the } \\
\text { provision of } \\
\text { legal services } \\
\text { complementary } \\
\text { to the tax } \\
\text { function. } \\
\text { Legal and finan- } \\
\text { cial press pro- } \\
\text { claims Big } \\
\text { Four's drive to } \\
\text { become major } \\
\text { players in law } \\
\text { is "dead." }\end{array}$ & $\begin{array}{l}\text { Stage 4: Inte- } \\
\text { grated MDP } \\
\text { Gaps in SOX } \\
\text { allow the Big } \\
\text { Four to renew } \\
\text { their commit- } \\
\text { ment to an } \\
\text { MDP approach. } \\
\text { The enactment } \\
\text { of the UK } \\
\text { 2007 Legal } \\
\text { Services Act } \\
\text { reinforces a } \\
\text { friendlier } \\
\text { approach to } \\
\text { MDPs. } \\
\text { The } 2008 \text { finan- } \\
\text { cial crisis and } \\
\text { the rise of } \\
\text { emerging mar- } \\
\text { kets, increases } \\
\text { the demand } \\
\text { for global cost- } \\
\text { efficient legal } \\
\text { services. } \\
\text { The Big Four } \\
\text { embark on the } \\
\text { global rebuild- } \\
\text { ing of FLPs, } \\
\text { structured } \\
\text { mostly as fully } \\
\text { integrated } \\
\text { MDPs. } \\
\text { The Big Four } \\
\text { reemerge as } \\
\text { important } \\
\text { players in the } \\
\text { market for } \\
\text { legal services, } \\
\text { particularly in } \\
\text { Europe and } \\
\text { emerging mar- } \\
\text { kets in Asia, } \\
\text { Latin America, } \\
\text { and Africa. }\end{array}$ & $\begin{array}{l}\text { Stage 5: Integrated } \\
\text { solutions } \\
\text { Emergence of } \\
\text { potentially dis- } \\
\text { ruptive tech- } \\
\text { nologies and } \\
\text { business mod- } \\
\text { els in the } \\
\text { professional } \\
\text { services } \\
\text { industries. } \\
\text { Shift to an inte- } \\
\text { grated solu- } \\
\text { tions business } \\
\text { model, through } \\
\text { the combina- } \\
\text { tion of the Big } \\
\text { Four's core } \\
\text { professional } \\
\text { services with } \\
\text { IT-led new } \\
\text { capabilities. } \\
\text { The UK Solici- } \\
\text { tors Regulation } \\
\text { Authority } \\
\text { grants EY, } \\
\text { KPMG, and } \\
\text { PwC alterna- } \\
\text { tive business } \\
\text { structures } \\
\text { licenses to } \\
\text { operate as fully } \\
\text { integrated } \\
\text { MDPs. } \\
\text { Global marketing } \\
\text { campaign to } \\
\text { promote the } \\
\text { integration of } \\
\text { law into a sol- } \\
\text { utions model } \\
\text { to "run the } \\
\text { company" as } \\
\text { superior to the } \\
\text { law firm "bet } \\
\text { the company" } \\
\text { model. }\end{array}$ \\
\hline
\end{tabular}


a new integrated approach to professional service built around the twin pillars of quality and integration (EY 2012b).

In the years since the period of crisis and renewal, the Big Four have taken a number of steps to transform and, ultimately, to transcend the federal model that they pursued in the 1990s. Although each firm's approach to these issues has been different, there are core similarities among their actions-similarities that have paradoxically both sharpened the differences and blurred the lines between the Big Four and the law firms with which they increasingly compete.

At the heart of this effort is a sustained commitment by each of the Big Four since 2005 to put integration and risk management at the core of its strategy, and to do so across all countries and service lines. The goal is to ensure that the "right" people work for the "right" clients—and that they deliver the "right" services to these clients (EY 2011). As Noordegraaf's $(2011,1358)$ research on emerging forms of "organized professionalism" underscores, this "organized response" has played a key role in rehabilitating the legitimacy of the Big Four's multidisciplinary and multinational professional workforce, which had seen its "creditworthiness" highly diminished as a result of Enron and other accounting scandals (Mawdsley and Somaya 2015, 223; Greenwood et al. 2005).

To signal this new creditworthiness, the Big Four are moving aggressively to integrate their FLPs within their international networks, thereby subjecting them to the same hierarchical controls, branding, strategy, processes, standards, and values as the rest of the business. These efforts to achieve greater harmonization and control are in turn reinforced by sophisticated client management systems and a culture of reciprocity under which lawyers working in their legal practices worldwide play multiple roles simultaneously-for example, as part of the legal service line, an industry group, a particular geographic location, and a number of client teamsthereby interacting with other professionals with different expertise (e.g., tax, consulting, accounting, financial, or industry-specific or local expertise) around the world (Greenwood et al. 2010; Hydle, Kvålshaugen, and Breunig 2014). Greenwood et al. (2010) label this form of matrix organization "multiplex," although as several scholars have noted, this terminology may overstate the degree to which the Big Four have actually achieved transnational integration (Boussebaa and Morgan 2015; Spence et al. 2015).

But even if the accountancy network's new integrated solutions model is currently more rhetoric than reality, the Big Four are nevertheless using this rhetoric to attempt to gain a competitive advantage over law firms. As EY's UK chairman and regional managing partner for the United Kingdom and Ireland recently argued, having client-facing lawyers working "side-by-side" with accountants and other professional advisors worldwide on large transactions, employment structures, or group reorganizations provides a "better level of service" than "the business models of traditional law firms" (Legal Business 2014). This argument is well positioned to appeal to the interests of many companies in the wake of the 2008 financial crisis. With global economic and regulatory uncertainty threatening the sustainability and growth prospects of multinational companies, these clients have increasingly demanded legal advisors who "understand our business," and who can provide value for money (Wilkins 2010, 2090). 
The Big Four understood this need far more quickly than many law firms, particularly in Europe and other markets where lawyers have traditionally seen themselves as separate and distinct from business. The accountancy firms therefore moved in aggressively to offer a suite of services through their increasingly integrated legal networks to corporate clients at the intersection of law and business, most of which were outside of the reserved categories that could be provided only by entities wholly owned and controlled by lawyers. As Ian Tod, Global CEO of Deloitte Legal, boldly declared: "The ones thinking that law as such is the most essential thing about our work do not get the point. The reason we are here is to help and advise our clients-that is the purpose of our work. And in the context of local law, this is valid globally" (Deloitte 2013d).

Similarly, the Big Four have also set out to prove that their model can provide a "better level of service" for today's top legal talent. Since 2002, the Big Four have transformed their human capital model in a way that they believe further differentiates them from traditional law firms, giving the accountancy giants a surprising edge in the war for talent. It is no secret that law firms have become very difficult places to work, particularly in the years following the global financial crisis (Ackroyd and Muzio 2007; Burk and McGowan 2011). Leveraging their culture of "global teaming," as well as express policies designed for "building a better working world," as EY's logo states (EY 2015c), the Big Four are increasingly attempting to exploit the perceived difficulty of life in large law firms to increase their attractiveness to top talent in the legal market.

The results have been impressive, particularly in Europe. For example, for two years in a row Deloitte Legal was recognized as the most attractive law firm employer by Czech law students (Deloitte 2013a). Similarly, in 2013, Taj, Deloitte's affiliated French law firm, received the "Business Case of Action" award for its exemplary actions in favor of gender equality at the Women's Empowerment Principles Event organized by the United Nations (Deloitte 2013c). Awards of this kind are particularly meaningful for millennial lawyers, as are the promises of challenging and interesting work (Malhotra, Smets, and Morris 2016) for "entrepreneurially minded" and "opportunistic" lawyers who are "driven to make a difference" that Big Four firms now advertise on their Web sites (Deloitte 2016b). As a result, in addition to recruiting top laterals as we indicated in Section III (Life After SOX), the Big Four are increasingly able to recruit top students directly out of law school in many jurisdictions, as the author of this article who teaches in a law school in Spain can readily attest. Indeed, even in the United States, where regulatory bans barring organizations not fully owned and operated by lawyers from practicing law are the strongest, the author who teaches in a US law school has seen several examples of the Big Four recruiting LLM graduates to work in the firm's offices around the globe.

Finally, in addition to promising greater integration of law and business, and new and more attractive approaches to talent development, the Big Four are also attempting to leverage their expertise in technology and project management to develop innovative approaches to delivering legal services that build on the disruptive innovations of tomorrow. To develop "support services that increase efficiency and reduce costs of routine legal activities" (EY 2015b), in the years following SOX the Big Four pioneered the unbundling of tax and legal services through 
sophisticated IT-enabled project management systems and the creation of "offshore units in low cost locations" (Sako 2015, 335).

Three recent moves by Deloitte highlight that the Big Four continue to want to be on the frontier of the integration of law and technology. In 2014, Deloitte acquired ATD Legal, one of the few providers of managed document review services in Canada (Deloitte 2014a). In 2016, Deloitte (2016c) acquired Conduit Law Professional Corp., a provider of outsourced lawyers ranked by the Financial Times (2015) as being among the "Most Innovative North American Law Firms 2015." That same year, Deloitte announced that it was forming an alliance with Kira Systems, which has been described by the company's CEO Noah Waisberg as "the largest professional services AI [artificial intelligence] deployment anywhere, period” (Deloitte 2016d; Kira 2016; Legal Insider 2016). The fact that all three of these moves involve legal technology companies whose primary clients are companies located in North America and the United Kingdom underscores that Deloitte intends to market its new integrated solutions model in these jurisdictions aggressively.

Indeed, the Big Four have demonstrated that they intend to move aggressively into the technology market far beyond the confines of legal tech to transform the nature of professional work generally. Thus, in 2014, $\mathrm{PwC}$ announced a joint business relationship with Google for Work to cocreate innovative solutions for clients. As PwC's Global chairman explained: "We bring in the content, they bring in the technology" (Google and PwC 2014). The same year, KPMG and McLaren Technology Group formed a strategic alliance building on KPMG's "strategy of investing in data and analytics and technological expertise" (KPMG 2014). Similarly, in 2015, EY established an alliance with LinkedIn aimed to "help companies develop deeper and more trusted customer relationships through the use of social and data analytics" (EY 2015a). In 2016, Deloitte announced a partnership with Apple to create "a first-of-its-kind Apple practice with over 5,000 strategic advisors who are solely focused on helping businesses change the way they work across their entire enterprise" (Deloitte 2016a).

It remains to be seen how these moves will impact the Big Four's global legal businesses. At a minimum, however, these new alliances signal the extent to which their new integrated solutions model aspires to move far beyond the traditional boundaries that defined their approach to MDPs in the 1990s.

Where the new boundary lines will ultimately be drawn around this new model remains an open question. In industrial management, scholars define an "integrated solutions" model as "longitudinal relational processes, during which a solution provider integrates goods, service and knowledge components into unique combinations that solve strategically important customer specific problems, and is compensated on the basis of the customer's value-in-use" (Storbacka 2011, 699). By combining their core professional services (assurance, advisory, and tax and legal) with new capabilities such as strategy consulting, on-demand talent models, cognitive technologies, cloud computing, digital applications, cyber security, and crisis services, the Big Four appear to be following a similar strategy. Although this strategy will undoubtedly target some high-end work by providing customized solutions to unique problems (Hansen, Nohria, and Tierney 1999), unlike elite law firms, the Big Four have not confined the application of their new model to 
premium services. Instead of focusing all their attention on landing the "bet the company" case, the Big Four are leveraging the full range of their knowledge and expertise to develop innovative business solutions to help their clients "run the company" efficiently and effectively.

PwC's recently announced partnership with GE is a case in point. In 2017, $\mathrm{PwC}$ and GE agreed that PwC would create a "Global Enterprise Tax Solutions Team" to provide GE with integrated, enterprise managed tax services on a global basis. According to PwC's website, "[a]s part of this agreement, $\mathrm{PwC}$ will hire more than 600 of GE's highly regarded tax team members from around the world and acquire GE's tax technologies to further both PwC's focus on the 'Tax Function of The Future' and the provision of global enterprise tax solutions to the marketplace" (PwC 2017). Most of the tax work that $\mathrm{PwC}$ will be doing for $\mathrm{GE}$ as a result of this deal would not be considered premium by the tax departments of most top law firms. There can be little doubt, however, that $\mathrm{PwC}$ now has a premium place at the table where one of the world's largest companies will be navigating the increasingly important intersection of law, tax, finance, and corporate strategy.

\section{CONCLUSION}

In a prescient article published in 2002, the US legal scholar Robert Eli Rosen hypothesized that changes in the corporate market for legal services were turning both in-house counsel and outside firms into just consultants whose primary task is to integrate legal knowledge into cross-functional teams to better achieve business objectives. In the decade since Rosen's article was published, changes in the economic and regulatory climate have only accentuated the trend he describes (Wilkins 2010).

Thus, corporate clients are increasingly demanding that their legal advisors understand their business, work collaboratively with business leaders and other professionals, and generally justify their service in terms of its contribution to the bottom line. The fact that since the onslaught of the global financial crisis companies have had to procure such services in an environment that increasingly demands that all participants produce more for less has only heightened the pressure on all lawyers to demonstrate that they know how to deliver commercially oriented legal services efficiently. Indeed, as commentators such as Richard Susskind (2008) in the United Kingdom and Larry Ribstein (2010) in the United States have suggested, these cost pressures, when combined with predicted increases in the speed and sophistication of information technology, may very well lead many commercial clients to seek to integrate legal advice directly into business processes through "smart" systems capable of being used by "legally trained" business people with minimal oversight and supervision by formally trained lawyers.

Whether all these trends result in the "End of Lawyers" (Susskind 2008) or the "Death of Big Law" (Ribstein 2010), as some scholars have predicted with growing apocalyptic fervor, they are very likely to further the legal ambitions of the Big Four. To the extent that the world of law is increasingly turning to traditional business methods such as unbundling, outsourcing, process management, and partnering 
to reduce costs and increase effectiveness, the legal networks of the global accounting firms have a distinct advantage. As Table 8 documents, the Big Four have successfully utilized all these processes to transform their practice from the nascent MDP model of the 1980s into the integrated solutions model that they are seeking to promote today.

Law firms, however, are unlikely to go gently into the good night some have predicted for them. Indeed, several prominent law firms are attempting to expand into the domain of other professional service providers the way that the Big Four are expanding into theirs. For example, in 2015, DLA Piper International LLP entered the field of corporate and financial advisory services by incorporating Noble Street Limited in the United Kingdom. While Noble Street and DLA Piper "operate as separate businesses," the focus is on cross-selling financial and consulting services to the law firm's strong international client base (Legal Business 2015; Noble Street 2016). The launch of Noble Street follows a wave of international law firms entering the corporate advisory field since 2010, thus acknowledging clients' demand for external legal advisors who "understand their issues, focus on delivering solutions to their challenges and share the risks with them"-as boldly claimed by the law firm Bird \& Bird (2015) on the occasion of the creation of a joint venture with ASE Consulting.

At the end of the day, however, the fact that several of the largest and most influential global law firms are now advertising themselves in ways that are indistinguishable from the Big Four's self-presentation dramatically underscores just how much the legal world as a whole has moved to the latter's terrain. When one adds the fact that much of the global legal services market is also shifting rapidly toward emerging markets in Asia, Latin America, Eastern Europe, and Africa where the Big Four already have a significant presence-including with respect to their legal networks - the potential for the Big Four to carve out an even more dominant position in the global market for corporate legal services becomes even more apparent.

Only time will tell whether these changes will finally allow the Big Four to achieve their renewed ambition not only to be important players in the global market for legal services, but also to reshape the very definition of that market toward a view that law is simply one part of achieving a "globally integrated business solution." This article contributes to this process by highlighting, through the integrative lens suggested by Empson et al. (2015), the deep organizational changes taking place in contemporary MDPs. Further research will be needed to determine how PwC, KPMG, Deloitte, and EY navigate the professional, managerial, and technological challenges inherent in deploying their new integrated solution business model, and how doing so will affect their core professional markets, and the global market for professional services generally. The challenges of seeking to redraw these boundaries are likely to be formidable. As Phillip Goodstone, EY's head of Law in the United Kingdom and Ireland, perceptively states, the firm's competitors are "whoever is strong in any market EY Law is competing for work" (Fouzder 2016). For now, we simply conclude by urging that academics and practitioners pay greater attention to how these important players are attempting to redraw the boundaries of professional services, and 
to how law firms, clients, and regulators respond to the potentially disruptive, but still largely unexplored, changes that the Big Four are bringing to the global legal services market.

\section{REFERENCES}

Abdelzaher, Dina M. 2012. The Impact of Professional Service Firms' Expansion Challenges on Internationalization Processes and Performance. Service Industries Journal 32 (10):1721-38.

Ackroyd, Stephen, and Daniel Muzio. 2007. The Reconstructed Professional Firm: Explaining Change in English Legal Practices. Organization Studies 28 (5):729-47.

AHK. 2015. Deloitte Legal Germany-Raupach Becomes Deloitte Legal. German Australian Chamber of Commerce, News \& PR, February 23. http://australien.ahk.de/news-pr/membernews/news-single-view-members/artikel/deloitte-legal-germany-raupach-becomes-deloittelegal/?cHash=d707ba53a5d25a797d54a885a6110f4d (accessed September 22, 2015).

ALB. 2010. ALB's Leading Tax Law Firms. Asian Legal Business. http://asia.legalbusinessonline. com/surveys-and-ranking/albs-leading-tax-law-firms/41225 (site no longer active).

Alles, Michael G., Alexander Kogan, and Miklos A. Vasarhelyi. 2005. Implications of Section 201 of the Sarbanes-Oxley Act: The Role of the Audit Committee in Managing the Informational Costs of the Restriction on Auditors Engaging in Consulting. International Journal of Disclosure and Governance 2 (1):9-26.

American Lawyer. 2015. The 2015 Am Law 100: Rich and Richer. American Lawyer, April 27. http://www.americanlawyer.com/id=1202489912232/The-2015-Am-Law-100-Rich-and-Richer? slreturn $=20151008112251$ (accessed November 7, 2015).

Arnold, Patricia J. 2005. Disciplining Domestic Regulation: The World Trade Organization and the Market for Professional Services. Accounting, Organizations and Society 30:299-330.

Aronson, Bruce E. 2007. Elite Law Firm Mergers and Reputational Competition: Is Bigger Really Better-An International Comparison. Vanderbilt Journal of Transnational Law 40 (3):763-832.

Australian Business Review. 2014. Shake-Up As Accountants Beef Up Law. Australian Business Review, August 21. http://www.theaustralian.com.au/business/legal-affairs/shakeup-as-accountantsbeef-up-law/story-e6frg97x-1227032415299?nk =fafa685d75fec192736b79d263f5c328-1443536664 (accessed November 7, 2015).

Barrett, Matthew J. 2004. "Tax Services" as a Trojan Horse in the Auditor Independence Provisions of Sarbanes-Oxley. Michigan State Law Review 1:463-504.

Basil, Debra Z., and Jill Erlandson. 2008. Corporate Social Responsibility Website Representations: A Longitudinal Study of Internal and External Self-Presentations. Journal of Marketing Communications 14 (2):125-37.

Baxter, James, and Richard Tromans. 2003. KPMG Ditches Legal Ambitions in KLegal Split. Legal Week, November 6. http://www.legalweek.com/legal-week/news/1164145/kpmg-ditcheslegal-ambitions-klegal-split (accessed February 24, 2015).

Bird \& Bird. 2015. Law Firm Bird \& Bird Partners Launch Unique Joint Venture with ASE Consulting, Specialists in IT-Enabled Change Programmes. Press release, February 10. http://www.twobirds.com/en/news/press-releases/2015/uk/bird-and-bird-partners-launch-joint-venture-with-ase-consulting (accessed May 30, 2016).

Bondy, Krista, Dirk Matten, and Jeremy Moon. 2004. The Adoption of Voluntary Codes of Conduct in MNCs: A Three-Country Comparative Study. Business and Society Review 109 (4):449-77.

Boussebaa, Mehdi, and Glenn Morgan. 2015. The Internationalization of Professional Service Firms: Drivers, Forms and Outcomes. In Oxford Handbook of Professional Service Firms, ed. Laura Empson, Daniel Muzio, Joseph P. Broschak, and Bob Hinings, 71-91. Oxford: Oxford University Press.

Boyd, Colin. 1999. The Transformation of the Accounting Profession: The History Behind the Big 5 Accounting Firms Diversifying into Law. Report prepared for the Canadian Bar Association International Practice of Law Committee on Multi-Disciplinary Practices and the 
Legal Profession, May 13. http://www.edwards.usask.ca/faculty/colin\%20boyd/personal/FinalCBAReport.htm (accessed February 24, 2015).

Brock, David M., and Michael J. Powell. 2005. Radical Strategic Change in the Global Professional Network: The "Big Five" 1999-2001. Journal of Organizational Change Management 18 (5):451-68.

Broomhall, Elizabeth. 2014. PwC to Double Lawyer Headcount in Asia as Part of Bold Regional Expansion Plan. Legal Week, April 8. http://www.legalweek.com/legal-week/news/2338598/ pwc-looks-to-double-lawyer-headcount-in-asia-as-part-of-bold-regional-growth-plan (accessed November 7, 2015).

Burk, Bernard A., and David McGowan. 2011. Big But Brittle: Economic Perspectives on the Future of the Law Firm in the New Economy. Columbia Business Law Review 1 (1):1-117.

Chambers \& Partners. 2011. PricewaterhouseCoopers Laos. http://www.chambersandpartners.com/ search/?PRICEWATERHOUSECOOPERS (site no longer active).

Collins, Anthony. 2006. French Legal Review Prompts Deloitte/Taj Reunion. Legal Week, March 2. http://www.legalweek.com/legal-week/news/1175718/french-legal-review-prompts-deloittetaj-reunion (accessed November 3, 2011).

Datamonitor. 2006. Global Legal Services. Industry Profile. December. http://www.datamonitor. com (accessed November 2, 2015).

Deloitte. 2012a. Deloitte's Affiliated Law Firm Changes Name to Deloitte Tax Law LLP. Deloitte press release, January 12. http://www.deloitte.com/view/en_CA/ca/pressroom/ca-pressreleasesen/d818dc49f09d4310VgnVCM1000001a56f00aRCRD.htm (accessed March 3, 2012).

—. 2012b. Global—Services. http://www.deloitte.com/view/en_GX/global/services/index.htm (accessed May 10, 2012).

2013a. Deloitte Legal Ranked as the Most Attractive Employer Among Students. Press release. http://www.deloittelegal.cz/en/deloitte-legal-ranked-as-the-most-attractive-employeramong-students.html (site no longer active).

. 2013b. Global. Services. Legal. Deloitte Legal. http://www.deloitte.com/view/en_GX/global/ services/deloitte-legal/index.htm (accessed April 10, 2013).

. 2013c. Innovation and Idea Generation Are the Top Outcomes from Gender Diversity. Deloitte's International Women's Day survey, press release, March 6. http://www2.deloitte. $\mathrm{com} / \mathrm{am} / \mathrm{en} /$ pages/about-deloitte/articles/innovation-and-idea-generation-are-the-top-outcomesfrom-gender-diversity.html (accessed November 7, 2015).

. 2013d. Interview with Global CEO of Deloitte Legal Ian Tod for Hospodárské noviny." Hospodářské Noviny (Czech daily business newspaper), March 13. http://www.deloittelegal.cz/ en/interview-with-global-ceo-of-deloitte-legal-ian-tod-for-hospodarske-noviny-html (accessed April 30, 2013).

. 2013e. Reff \& Associates Reports a 20\% Growth in 2012. Deloitte press release, March 12. http://www.deloitte.com/view/en_RO/ro/press/638de242f1f5d310VgnVCM3000003456f70aRCRD. htm (accessed April 4, 2013).

. 2014a. Deloitte Acquires ATD Legal Services. January 20. http://www2.deloitte.com/ca/en/ pages/press-releases/articles/deloitte-acquires-atd-legal.html (accessed May 5, 2016).

—. 2014b. Deloitte China. Legal. http://www.deloitte.com/view/en_CN/cn/services/legalserv/ index.htm (accessed March 2014).

. 2015a. About Us. Making a Positive, Enduring Impact that Matters. http://www2.deloitte. $\mathrm{com} / \mathrm{global} / \mathrm{en} /$ pages/about-deloitte/articles/gx-purpose-positive-enduring-impact-that-matters. html (accessed September 25, 2015).

2015b. Deloitte Legal. Global. http://www2.deloitte.com/global/en/services/legal.html (accessed November 11, 2015).

. 2015c. Deloitte Legal Rechtsanwaltsgesellschaft mbH—Home. http://www.deloittelegal.de/ en/ (accessed February 24, 2015).

. 2016a. Apple \& Deloitte Team Up to Accelerate Business Transformation on iPhone \& iPad. Press release, Cupertino, CA and New York, September 28. https://www2.deloitte.com/ global/en/pages/about-deloitte/articles/apple-deloitte-team-press-release.html (accessed October 20, 2016). 
—. 2016b. Deloitte. About Deloitte Legal. https:/www2.deloitte.com/global/en/pages/legal/solutions/about-deloitte-legal.html (accessed May 24, 2016).

. 2016c. Deloitte Announces Affiliation with Conduit Law. Deloitte Press Release. Toronto, March 14. http://www2.deloitte.com/ca/en/pages/press-releases/articles/deloitte-announcesaffiliation-with-conduit-law.html (accessed May 15, 2016).

. 2016d. Deloitte Forms Alliance with Kira Systems to Drive the Adoption of Artificial Intelligence in the Workplace. Deloitte press release, New York, March 8. http://www2.deloitte.com/ us/en/pages/about-deloitte/articles/press-releases/deloitte-forms-alliance-with-kira-systems-to-drivethe-adoption-of-artificial-intelligence-in-the-workplace.html (accessed May 4, 2016).

Dezalay, Yves, and Bryant G. Garth. 2004. The Confrontation Between the Big Five and Big Law: Turf Battles and Ethical Debates as Contests for Professional Credibility. Law $\mathcal{E}$ Social Inquiry 29 (3):615-38.

DLA Piper. 2017. Legal Notices. https://www.dlapiper.com/en/us/legalnoticespage/ (accessed January 21, 2017).

Dowell, Katy. 2014. Deloitte Prepares to Take on the UK Legal Market. Lawyer, June 9. https:// www.thelawyer.com/issues/online-june-2014/deloitte-prepares-to-take-on-the-uk-legal-market/ (accessed January 9, 2017).

Economist. 2003. Accountancy and Law: Back to Basics. Economist, November 13. http://www. economist.com/node/2216250 (accessed November 15, 2011).

Empson, Laura, Daniel Muzio, Joseph P. Broschak, and Bob Hinings. 2015. Introduction. In Oxford Handbook of Professional Service Firms, ed. Laura Empson, Daniel Muzio, Joseph P. Broschak, and Bob Hinings, 1-24. Oxford: Oxford University Press.

Esteban Ferrer, María J., and David B. Wilkins. 2013. Regreso Al Futuro: La Reactivación de Las Divisiones Jurídicas de Las Big 4 En Europa y El Futuro de La Abogacía de Los Negocios. Economist $\mathcal{E}$ Jurist 21 (167):81-90.

European Commission. 2011. Proposal for a Directive of the European Parliament and of the Council Amending Directive 2006/43/EC on Statutory Audits of Annual Accounts and Consolidated Accounts and a Proposal for a Regulation of the European Parliament and of the Council on Specific Requirements Regarding Statutory Audit of Public-Interest Entities. Commission Staff Working Paper, Impact Assessment, Brussels, November 30, SEC (2011), 1384 final. http://ec.europa.eu/internal_market/auditing/docs/reform/impact_assesment_en.pdf (accessed March 10, 2015).

EY. 2011. Ernst \& Young Global Review 2011. http://www.ey.com/GL/en/About-us/Our-globalapproach/Global-review/Global-review-2011 (accessed March 10, 2012).

. 2012a. Ernst \& Young Global Services. http://www.ey.com/GL/en/Services (accessed March $10,2012)$.

2012b. Global Review 2012. http://www.ey.com/GL/en/About-us/Our-global-approach/ Global-review/Global-review-2012 (accessed May 2013).

. 2012c. Integrated Annual Review 2011/2012. Ernst \& Young Nederland LLP. http://www.ey. com/Publication/vwLUAssets/Jaarverslag_-_2011-2012/\$FILE/Annual\%20Review\%20-\%2020112012.pdf (accessed March 2013).

—. 2014. EY Recruits Freshfields Partner Richard Norbruis to Join Global Law Leadership. Newsroom, London, June 3. http://www.ey.com/GL/en/Newsroom/News-releases/News-Freshfieldspartner-Richard-Norbruis-to-join-Global-Law-Leadership (accessed September 10, 2015).

2015a. EY and LinkedIn Enter into Alliance to Help Accelerate Growth in the Business-toBusiness Market. London, October 29. http://www.ey.com/GL/en/Newsroom/News-releases/newsey-and-linkedin-enter-into-alliance-to-help-accelerate-growth-in-the-business-to-business-market (accessed November 7, 2015).

2015b. Law: Passion for Excellence Across the Globe. http://www.ey.com/GL/en/Services/ Tax/Law (accessed November 7, 2015).

—. 2015c. Our People—A Diverse 21st-Century Workforce. http://www.ey.com/GL/en/Aboutus/Our-people-and-culture (accessed November 7, 2015).

Faulconbridge, James, and Daniel Muzio. 2016. Global Professional Service Firms and the Challenge of Institutional Complexity: "Field Relocation" as a Response Strategy. Journal of Management Studies 53 (1):89-124. 
Financial Times. 2015. North America Innovative Lawyers 2015. Financial Times. http://rankings.ft.com/usil/most-innovative-north-american-law-firms-2015-most-innovative-canadianfirms (accessed April 20, 2016).

Flood, John. 2011. The Re-Landscaping of the Legal Profession: Large Law Firms and Professional Re-Regulation. Current Sociology 59 (4):507-29.

Fouzder, Monidipa. 2016. Profession Struggling to "Figure Out" EY Law. Law Society Gazette, January 18. https://www.lawgazette.co.uk/practice/profession-struggling-to-figure-out-ey-law/ 5053069.article (accessed March 12, 2016).

Garth, Bryant G. 2004. Multidisciplinary Practice After Enron: Eliminating a Competitor But Not the Competition. Law EO Social Inquiry 29 (3):591-95.

Garth, Bryant G., and Carole Silver. 2002. The MDP Challenge in the Context of Globalization. Case Western Reserve Law Review 52 (4):903-42.

Google and PwC. 2014. PwC and Google Announce Joint Business Relationship Collaboration to Help Companies Thrive in a Changing World. New York, October 28. http://google.pwc. com/docs/PwC_Google_Press_Release.pdf (accessed November 7, 2015).

Grady, Kenneth. 2016. Why Law Firm Referral Networks Fall Short. Seyt Lines, October 13. http://www.seytlines.com/2016/10/why-law-firm-referral-networks-fall-short/ (accessed January 20, 2017).

Greenwood, Royston, Tim Morris, Samantha Fairclough, and Mehdi Boussebba. 2010. The Organizational Design of Transnational Professional Service Firms. Organizational Dynamics 39 (2):173-83.

Greenwood, Royston, and Roy Suddaby. 2006. Institutional Entrepreneurship in Mature Fields: The Big Five Accounting Firms. Academy of Management Journal 49 (1):27-48.

Greenwood, Royston, Stan Li X, Rajshree Prakash, and David L. Deephouse. 2005. Reputation, Diversification, and Organizational Explanations of Performance in Professional Service Firms. Organization Science 16 (6):661-73.

Griffiths, Catrin. 2004. Leader. Lawyer, March 1. http://www.thelawyer.com/leader/108647.article (accessed November 7, 2015).

Gwilliam, David, Chie Min Teng, and Oliver Marnet. 2014. How Does Joint Provision of Audit and Non-Audit Services Affect Audit Quality and Independence? A Review. ICAEW. http://www.icaew.com/en/products/audit-and-assurance-publications/ /media/481bd2be6ac7414cb4248996d259f8 f5.ashx (accessed September 10, 2015).

Halliburton, Chris, and Agnes Ziegfeld. 2009. How Do Major European Companies Communicate Their Corporate Identity Across Countries?-An Empirical Investigation of Corporate Internet Communications. Journal of Marketing Management 25 (9-10):909-25.

Hamel, Gary, and Liisa Välikangas. 2003. The Quest for Resilience. Harvard Business Review 81 (9):52-65.

Hansen, Morten T., Nitin Nohria, and Thomas J. Tierney. 1999. What's Your Strategy for Managing Knowledge? Harvard Business Review. https://hbr.org/1999/03/whats-your-strategy-formanaging-knowledge (accessed October 12, 2014).

Harris, Joanne. 2011. Clifford Chance Follows A\&O with Casablanca Launch. Lawyer, July 25. http://www.thelawyer.com/1008743.article (accessed April 4, 2013).

Hinings, C. Robert, Royston Greenwood, and David Cooper. 1999. The Dynamics of Change in Large Accounting Firms. In Restructuring the Professional Organization: Accounting, Health Care and Law, ed. David Brock, Michael J. Powell, and C. R. Hinings, 131-53. London: Routledge.

Hitt, Michael A., Leonard Bierman, Katsuhiko Shimizu, and R. Kochhar. 2001. Direct and Moderating Effects of Human Capital on Strategy and Performance in Professional Service Firms: A Resource-Based Perspective. Academy of Management Journal 44 (1):13-28.

Hitt, Michael A., Leonard Bierman, Klaus Uhlenbruck, and Katsuhiko Shimizu. 2006. The Importance of Resources in the Internationalization of Professional Service Firms: The Good, the Bad and the Ugly. Academy of Management Journal 49 (6):1137-57.

Holtzman, Yair. 2004. The Transformation of the Accounting Profession in the United States: From Information Processing to Strategic Business Advising. Journal of Management Development 23 (10):949-61. 
Hoult, Philip. 1998. Canada is Deloitte's Next Target. Lawyer, June 23. http://www.thelawyer. com/canada-is-deloittes039-next-target/91251.article (accessed November 3, 2011).

HVG. 2012. About Holland van Gijzen-Ernst \& Young-NW. http://www.hollandlaw.nl/NW/ en/About-our-firm (accessed March 10, 2012).

Hydle, Katja M., Ragnhild Kvålshaugen, and Karl Joachim Breunig. 2014. Transnational Practices in Communities of Task and Communities of Learning. Management Learning 45 (5): 609-29.

ICAEW. 2015. Alternative Business Structures. http://www.icaew.com/-/media/corporate/files/ technical/legal-and-regulatory/legal-services/abs-faqs-april-2015.ashx?la=en (accessed January 20, 2017).

Irwin, Sarah. 2013. Qualitative Secondary Data Analysis: Ethics, Epistemology and Context. Progress in Development Studies 13 (4):295-306.

Juve. 2012. German Legal Market 2011/2012: Developments and Trends. Juve Handbook. http:// www.juve.de/handbuch/en/2012/kapitel/u10/4 (accessed August 20, 2012).

—. 2015. Hamburg: Freshfields-Partner Nikolaus Schrader geht zu PwC Legal. Juve, February 3. http://www.juve.de/nachrichten/namenundnachrichten/2015/02/hamburg-freshfields-partnerschrader-geht-zu-pwc-legal (accessed November 7, 2015).

Kira. 2016. Deloitte. http://info.kirasystems.com/partners-deloitte-alliance (accessed May 5, 2016).

KPMG. 2012a. Greenberg Turner Joins KPMG Law LLP. KPMG Now Home to a Leading Global Immigration Law Firm. Press release, Toronto, November 1. http://www.kpmg.com/Ca/en/ IssuesAndInsights/ArticlesPublications/Press-Releases/Pages/Greenberg-Turner-joins-KPMGLaw.aspx (accessed May 10, 2013).

—. 2012b. KPMG Global. What We Do. http://www.kpmg.com/global/en/whatwedo/Pages/ default.aspx (accessed March 2012).

2012c. KPMG Law. http://www.kpmg.com/ca/en/services/tax/kpmg-law/Pages/default.aspx (accessed May 2013).

. 2014. KPMG and McLaren Strategic Alliance. Insights, November 1. https://home.kpmg.com/ uk/en/home/insights/2014/11/mclaren-strategic-alliance.html (accessed December 20, 2014).

. 2015a. Global Legal Services. https://home.kpmg.com/xx/en/home/services/tax/global-legalservices.html (accessed November 7, 2015).

. 2015b. KPMG Announces Record Number of New Partners. Australia. Press releases, June 22. http://www.kpmg.com/au/en/issuesandinsights/articlespublications/press-releases/pages/kpmg-announces-record-number-of-new-partners-22-jun-2015.aspx (accessed November 7, 2015).

Kriegler, Yun. 2014. EY Law Asia: We'll Double in Size in a Year. Lawyer, May 7. http://www. thelawyer.com/analysis/behind-the-law/ey-law-asia-well-double-in-size-in-a-year/3019872.article (accessed June 10, 2014).

Landwell. 2001. News Release, October 11. http://www.landwellglobal.com/images/uk/eng/custom/ uk_downloads/11.10.2001\%20-\%20new\%20manda\%20partner.pdf (site no longer active).

—. 2003. Capability Statement. http://www.landwellglobal.com/images/gx/eng/gx_downloads/ capStatement.pdf (accessed September 12, 2015).

—. 2013. Landwell \& Associés Société d'Avocats. Your Challenges, Our Skills. http://www.landwell.fr/multi-disciplinary-solutions-to-address-your-challenges.html (accessed January 11, 2013).

Law Society Gazette. 2001. On the Lookout. Law Society Gazette, August 21. http://www.lawgazette.co.uk/news/on-lookout (accessed April 3, 2013).

Lawyer. 1996a. Accountants on the Brink of Taking Law into Their Hands. Lawyer, December 11. http://www.thelawyer.com/accountants-on-the-brink-of-taking-law-into-their-hands/92514.article (accessed November 15, 2011).

—. 1996b. A Model Association. Lawyer, May 21. http://www.thelawyer.com/a-model-association/91520.article (accessed November 15, 2011).

- 2000. KLegal Tops £6m in Start-Up Salary Costs as KPMG Wages War on City. Lawyer, June 12. http://www.thelawyer.com/klegal-tops-6m-in-start-up-salary-costs-as-kpmg-wageswar-on-city/102953.article (accessed November 15, 2011).

2007a. 20 Years of The Lawyer: 1993. Lawyer, December 5. http://www.thelawyer.com/span$\mathrm{id}=$ red20-years-of-the-lawyer/span-1993/130261.article (accessed November 15, 2011). 
- 2007b. 20 Years of The Lawyer: 1997. Lawyer, December 5. http://www.thelawyer.com/spanid = red20-years-of-the-lawyer/span-1997/130265.article (accessed November 15, 2011).

Legal Business. 2014. "We Are Offering Something New": EY Latest Big Four Giant Granted ABS Licence. Legal Business, December 1. http://www.legalbusiness.co.uk/index.php/lb-blogview/3286-we-are-offering-something-new-ey-latest-big-four-giant-granted-abs-licence (accessed May 15, 2016).

—. 2015. A Noble Pursuit-DLA Piper Launches Corp Fin Boutique to Build TMT Profile. Legal Business, May 8. http://www.legalbusiness.co.uk/index.php/lb-blog-view/4124-a-noblepursuit-dla-piper-launches-corp-fin-boutique-to-build-tmt-profile (accessed May 15, 2016).

Legal Insider. 2016. Deloitte Partners with Kira Systems to Bring AI into the Workplace. Legal Insider, March 8. http://www.legaltechnology.com/latest-news/deloitte-partners-with-kira-systems-to-bring-ai-into-the-workplace/ (accessed May 15, 2016).

Levitt, Arthur. 2000. Speech by SEC Chairman: A Profession at the Crossroads. SEC: US Securities and Exchange Commission. National Association of State Boards of Accountancy. Boston, September 18. http://www.sec.gov/news/speech/spch399.htm (accessed April 18, 2013).

Lind, Sofia. 2010. DLA Piper City Partner Joins PwC Legal for Middle East Launch. Legal Week, February 11. http://www.legalweek.com/legal-week/news/1591385/dla-piper-city-partner-joinspwc-legal-middle-east-launch (accessed February 24, 2013).

Lindsay, Robert. 1997a. Ernst \& Young Hunt for Legal Head Lands Dentons Partner. Lawyer, September 16. http://www.thelawyer.com/ernst-and-young-hunt-for-legal-head-lands-dentonspartner/82231.article (accessed November 3, 2011).

1997b. KPMG Rules Out Growing Law Firm in Favour of New Alliance. Lawyer, November 2. http://www.thelawyer.com/kpmg-rules-out-growing-law-firm-in-favour-of-new-alliance/ 95654.article (accessed November 3, 2011).

Llopis, Juan M., Reyes González, and José L. Gascó. 2009. Análisis de páginas web corporativas como descriptor estratégico. Investigaciones Europeas de Dirección y Economía de La Empresa $15(3): 123-37$.

Loughrey, Joan. 2011. Corporate Lawyers and Corporate Governance. Cambridge: Cambridge University Press.

Malhotra, Namrata, Michael Smets, and Timothy Morris. 2016. Career Pathing and Innovation in Professional Service Firms. Academy of Management Perspectives 30 (4):369-83.

Marcos, Francisco. 2000. The Storm Over Our Heads: The Rendering of Legal Services by Audit Firms in Spain. International Journal of the Legal Profession 7 (1):7-38.

MarketLine. 2014. Accountancy Industry Profile: Global. MarketLine December 2014:124. http:// www.marketline.com (accessed November 7, 2015).

—. 2015. Legal Services Industry Profile: Global. MarketLine June 2015:1-28. http://www.marketline.com (accessed November 7, 2015).

Mawdsley, John, and Deepak Somaya. 2015. Strategy and Strategic Alignment in Professional Service Firms. In Oxford Handbook of Professional Service Firms, ed. Laura Empson, Daniel Muzio, Joseph P. Broschak, and Bob Hinings, 213-37. Oxford: Oxford University Press.

McKenna, Francine. 2011. Don't Count on Europe to Reform Auditors and Accounting. Forbes, September 27. http://www.forbes.com/sites/francinemckenna/2011/09/27/dont-count-oneurope-to-reform-auditors-and-accounting/2/ (accessed April 3, 2013).

McMillan, Sally J. 2000. The Microscope and the Moving Target: The Challenge of Applying Content Analysis to the World Wide Web. Journalism $\mathcal{E}$ Mass Communication Quarterly 77 (1):80-98.

Meyer, Katrina A. 2008. The "Virtual Face" of Institutions: Why Legislators and Other Outsiders View Higher Education as Aloof. Internet and Higher Education 11 (3-4):178-85.

Morgan, Glenn, and Sigrid Quack. 2005. Institutional Legacies and Firm Dynamics: The Growth and Internationalization of UK and German Law Firms. Organization Studies 26:1765-85.

Mullerat, Ramón. 1999. Report on Multidisciplinary Practices in Europe. Center for Professional Responsibility, American Bar Association, April. http://www.americanbar.org/groups/professional_responsibility/commission_multidisciplinary_practice/mullerat1.html (accessed February 24,2015$)$. 
Naiker, Vic, Divesh S. Sharma, and Vineeta D. Sharma. 2013. Do Former Audit Firm Partners on Audit Committees Procure Greater Non Audit Services from the Auditor? Accounting Review 88 (1):297-326.

Nnona, George C. 2006. Situating Multidisciplinary Practice Within Social History: A Systemic Analysis of Inter-Professional Competition. St. John's Law Review 80:849-921.

Noble Street. 2016. FAQs. http://www.noblestreet.com/?page_id=54 (accessed January 24, 2017).

Noordegraaf, Mirko. 2011. Risky Business: How Professionals and Professional Fields (Must) Deal with Organizational Issues. Organization Studies 32 (10):1349-71.

OECD. 2000. Report on Competition in Professional Services. DAFFE/CLP 2:1-214. http://www. oecd.org/regreform/sectors/1920231.pdf (accessed February 24, 2015).

Panteia and Maastricht University. 2012. Evaluation of the Legal Framework for the Free Movement of Lawyers. Report for European Commission/DG Internal Market and Services. Zoetermeer-Maastricht, November 28. http://ec.europa.eu/internal_market/qualifications/docs/ studies/2013-lawyers/report_en.pdf (accessed January 12, 2017).

Paton, Paul D. 2006. Rethinking the Role of the Auditor: Resolving the Audit/Tax Services Debate. Queen's Law Journal 32 (1):135-89.

— 2010. Multidisciplinary Practice Redux: Globalization, Core Values, and Reviving the MDP Debate in America. Fordham Law Review 78:2193-2244.

Picciotto, Sol. 1995. The Construction of International Taxation. In Professional Competition and Professional Power: Lawyers, Accountants and the Social Construction of Markets, ed. Yves Dezalay and David Sugarman, 25-50. London: Routledge.

Power, Helen. 2003. Survival Techniques. Lawyer, April 28. http://www.thelawyer.com/survivaltechniques/100919.article (accessed November 3, 2011).

PwC. 2011. PwC Global Legal Services Network. Country Content Page. Country Profile. United Arab Emirates. http://www.pwc.com/gx/en/legal/countries/index.jhtml?co=ae (accessed July 10, 2011).

—. 2012a. PwC Global-Our Services. http://www.pwc.com/gx/en/global-business-services/ index.jhtml (accessed March 12, 2012).

. 2012b. PwC Global Legal Services Network. Country Content Page. Country Profile. India. http://www.pwc.com/gx/en/legal/countries/index.jhtml?co=in (accessed March 8, 2012).

. 2014. PwC Spearheads Growth in Legal Services. Press release, August 15. http://www.pwc. com.au/media-centre/2014/growth-legal-services-aug14.htm (accessed November 7, 2015).

. 2015a. Global—Our Services—Legal Services. http://www.pwc.com/gx/en/legal/ (accessed February 24, 2015).

. 2015b. Landwell \& Associés devient PwC Société d'Avocats. Communiqué de presse, Neuilly-sur-Seine, March, 9. http://www.pwc.fr/landwell-and-associes-devient-pwc-societedavocats1.html (accessed November 7, 2015).

. 2016. PwC Legal Integrates into PwC UK to Become a Multi-Disciplinary Practice. PwC press room, September 30. http://pwc.blogs.com/press_room/2016/09/pwc-legal-integratesinto-pwc-uk-to-become-a-multi-disciplinary-practice.html (accessed November 30, 2016).

. 2017. PwC Announces New Global Corporate Tax Services Team. New York, January 12. http://www.pwc.com/us/en/press-releases/2017/global-corporate-tax-services-team.html (accessed February 7, 2017).

Quak, Sigrid, and Elke Shüßler. 2015. Dynamic of Regulation of Professional Service Firms: National and Transnational Developments. In Oxford Handbook of Professional Service Firms, ed. Laura Empson, Daniel Muzio, Joseph P. Broschak, and Bob Hinings, 48-70. Oxford: Oxford University Press.

Ratzinger-Sakel, Nicole V. S., and Martin W. Schönberger. 2015. Restricting Non-Audit Services in Europe-The Potential (Lack of) Impact of a Blacklist and a Fee Cap on Auditor Independence and Audit Quality. Accounting in Europe 12 (1):61-86.

Reckers, Philip M. J., Marianne Jennings, D. Jordan Lowe, and Kurt Pany. 2007. Judges' Attitudes Toward the Public Accounting Profession. European Accounting Review 16 (3): $625-45$.

Ribstein, Larry E. 2010. The Death of Big Law. Wisconsin Law Review 3:749-815. 
Richmond, Douglas R., and Matthew K. Corbin. 2014. Professional Responsibility and Liability Aspects of Vereins, the Swiss Army Knife of Global Law Firm Combinations. St. John's Law Review 88 (4):917-84.

Rogowski, Ralf. 1995. German Corporate Lawyers. Social Closure in Autopoietic Perspective. In Professional Competition and Professional Power: Lawyers, Accountants and the Social Construction of Markets, ed. Yves Dezalay and David Sugarman, 114-38. New York: Routledge.

Rosen, Robert E. 2002. "We're All Consultants Now": How Change in Client Organizational Strategies Influences Change in the Organization of Corporate Legal Services. Arizona Law Review 44:637-84.

Sako, Mari. 2015. Outsourcing and Offshoring of Professional Services. In Oxford Handbook of Professional Service Firms, ed. Laura Empson, Daniel Muzio, Joseph P. Broschak, and Bob Hinings, 327-50. Oxford: Oxford University Press.

Sarfo, Ama. 2013. Boom Times for Law Firms Aren't Returning Soon. Law360, January 14. https://www.law360.com/legalindustry/articles/406940/boom-times-for-law-firms-aren-t-returning-soon-study-says (accessed February 7, 2017).

Schmidt, Jaime J. 2012. Perceived Auditor Independence and Audit Litigation: The Role of Non Audit Services Fees. Accounting Review 87 (3):1033-65.

Segal-Horn, Susan, and Alison Dean. 2011. The Rise of Super-Elite Law Firms: Towards Global Strategies. Service Industries Journal 31 (2):195-213.

Spence, Crawford, Claire Dambrin, Chris Carter, Javier Husillos, and Pablo Archel. 2015. Global Ends, Local Means: Cross-National Homogeneity in Professional Service Firms. Human Relations 68 (5):765-88.

SRA. 2014a. Register of Licensed Bodies (ABS). Ernst \& Young LLP. Solicitors Regulation Authority. http://www.sra.org.uk/solicitors/firm-based-authorisation/abs-register/614947.page (accessed November 7, 2015).

—. 2014b. Register of Licensed Bodies (ABS). KPMG LLP. Solicitors Regulation Authority. http://www.sra.org.uk/solicitors/firm-based-authorisation/abs-register/615423.page (accessed November 7, 2015).

. 2016. Register of Licensed Bodies (ABS). PricewaterhouseCoopers LLP. Solicitors Regulation Authority. http://www.sra.org.uk/solicitors/firm-based-authorisation/abs-register/629994. page (accessed November 21, 2016).

Statista. 2017. Size of the Global Legal Services Market 2008-2014. https://www.statista.com/statistics/605125/size-of-the-global-legal-services-market/ (accessed February 4, 2017).

Stephen, Frank H. 2002. The European Single Market and the Regulation of the Legal Profession: An Economic Analysis. Managerial $\mathcal{E}$ Decision Economics 23 (3):115-25.

Storbacka, Kaj. 2011. A Solution Business Model: Capabilities and Management Practices for Integrated Solutions. Industrial Marketing Management 40 (5):699-711.

Suddaby, Roy, David J. Cooper, and Royston Greenwood. 2007. Transnational Regulation of Professional Services: Governance Dynamics of Field Level Organizational Change. Accounting, Organizations and Society 32:333-62.

Susskind, Richard. 2008. The End of Lawyers? Rethinking the Nature of Legal Services. Oxford: Oxford University Press.

Tafara, Ethiopis. 2006. Statement by SEC Staff: A Race to the Top: International Regulatory Reform Post Sarbanes-Oxley. International Financial Law Review, September. http://www.sec. gov/news/speech/2006/spch091106et.htm (accessed February 24, 2015).

Terry, Laurel S. 1999. A Primer on MDPs: Should the "No" Rule Become a New Rule. Temple Law Review 72:869-964.

2000. German MDPs: Lessons to Learn. Minnesota Law Review, 84:1547-1617. 2008. The Future Regulation of the Legal Profession: The Impact of Treating the Legal Profession as "Service Providers." Journal of the Professional Lawyer 18:189-211.

TheCityUK. 2016. UK Legal Services 2016. TheCityUK, July 2016. https://www.thecityuk.com/ assets/2016/Reports-PDF/UK-Legal-services-2016.pdf (accessed January 10, 2017).

Tromans, Richard. 2003a. E\&Y Bucks Trend and Tightens Legal Alliance. Legal Week, May 22. http://www.legalweek.com/legal-week/news/1157260/e-y-bucks-trend-tightens-legal-alliance (accessed September 6, 2011). 


\section{LAW \& SOCIAL INQUIRY}

—. 2003b. Landwell Retreats from PwC Link. Legal Week, March 13. http://www.legalweek. com/legal-week/news/1144012/landwell-retreats-pwc-link (accessed September 6, 2011).

Twain, Mark. 1906. Chapters from My Autobiography. North American Review, September 21, 1906.

Whealing, Justin. 2014. Exclusive: PwC Beats Globals to Get Former KWM Heads. Lawyers Weekly, August 15. http://www.lawyersweekly.com.au/news/15641-exclusive-pwc-beats-globals-to-get-former-kwm-head (accessed November 7, 2015).

Wilkins, David B. 2010. Team of Rivals? Toward a New Model of the Corporate Attorney-Client Relationship. Fordham Law Review 78 (5/2):2067-2136.

2015. Law Firms. In International Encyclopedia of the Social and Behavioral Sciences, 2d ed., ed. Roseann Greenspan and Kay Levin, 578-4. Oxford: Oxford University Press.

Wilkins, David B., and Mihaela Papa. 2013. The Rise of the Corporate Legal Elite in the BRICS: Implications for Global Governance. Boston College Law Review 54 (3):1149-67.

World Tax. 2011. PricewaterhouseCoopers. World Tax. http://www.itrworldtax.com/JurisdictionFirm/3953/6/PricewaterhouseCoopers (accessed July 2, 2011).

World Trade Organization. 2010. Legal Services. Background Note by the Secretariat, S/C/W/ 318, June 14. http://www.americanbar.org/content/dam/aba/migrated/cpr/gats/wto_legal_services.authcheckdam.pdf (accessed February 20, 2017).

Zhang, Anna. 2014. Deloitte Dabbles in Chinese Legal Practice. Asian Lawyer, January 27. http:// www.international.law.com/id=1202640056886/Deloitte-Dabbles-in-Chinese-Legal-Practice?slreturn $=20151008044512$ (accessed November 7, 2015).

Zhao, Jensen J., Allen D. Truell, and Melody W. Alexander. 2006. User-Interface Design Characteristics of Fortune 500 B2C E-Commerce Sites and Industry Differences. Delta Pi Epsilon Journal 48 (1):43-55.

Zeff, Stephen. 2003. How the U.S. Accounting Profession Got Where It Is Today: Part II. Accounting Horizons 17 (4):267-86.

\section{STATUTES CITED}

Directive 2006/43/EC of the European Parliament and of the Council of 17 May 2006 on statutory audits of annual accounts and consolidated accounts, amending Council Directives 78/ 660/EEC and 83/349/EEC and repealing Council Directive 84/253/EE. OJ L 157. June 9, 2006: 87-107.

Directive 2014/56/EU of the European Parliament and of the Council, of 16 April 2014, amending Directive 2006/43/EC on statutory audits of annual accounts and consolidated accounts, OJ L 158. May 27, 2014: 196-226.

Legal Services Act 2007 (c. 29), (October 30, 2007).

Sarbanes-Oxley Act of 2002, Public Law 107-204, 107th Cong., (July 30, 2002): 745-810. 


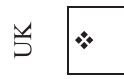

$\cong 00$

○

罚.

空

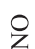

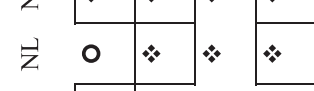

$\sum 0$

$\sum$.

马 000

$\Xi$.

필.

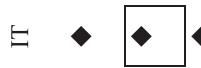

$\simeq 00$

되

00

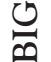

臰

告

告

究

$x^{2}$

当

«ำ

感

边

ن $\sum_{i}$

$x \underline{x}$

穴

Z

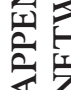

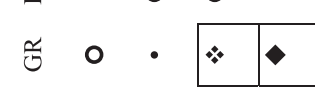

ت

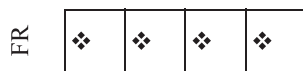

届 00000

里

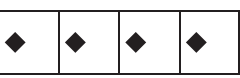

a 00

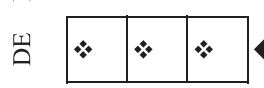

它 $* 0$

ت 0000

뎅 0

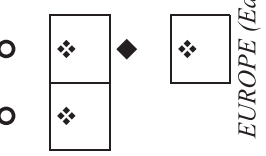

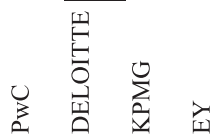

N

$\overleftrightarrow{5} 00000$

F

o

क $\cdot \cdot \cdot$

㟶

궁

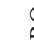

$\overrightarrow{2}$

$\stackrel{y}{\Sigma} 0$

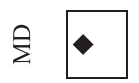

ב 000

$50 \cdot 0$

핀

v

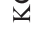

足 $\%$

멍 - 0

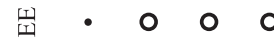

N

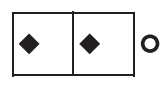

E

刍 0 .

窝

诡.

『 0 ・

$\circ 0$

0

ㄴ. 0

这.

兵

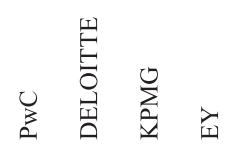

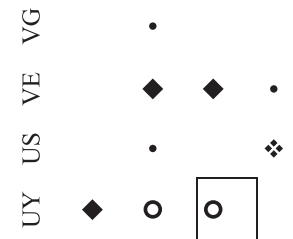

㫐

is 00

$\begin{array}{llll} \pm & 0 & 0 & \square \\ \vdots & 0 & 0\end{array}$

$\llbracket 00$

z 00

\begin{tabular}{ll|l}
\hline \multirow{2}{*}{} & 0 & 0 \\
\hline
\end{tabular}

䏠

z 0

$\sum$.

学 0

500

品 *

○

ชี 0

8

च

త

藏 $* 0$

ले.

品.

m 0

3

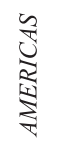

过

0 .

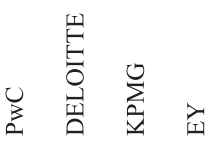




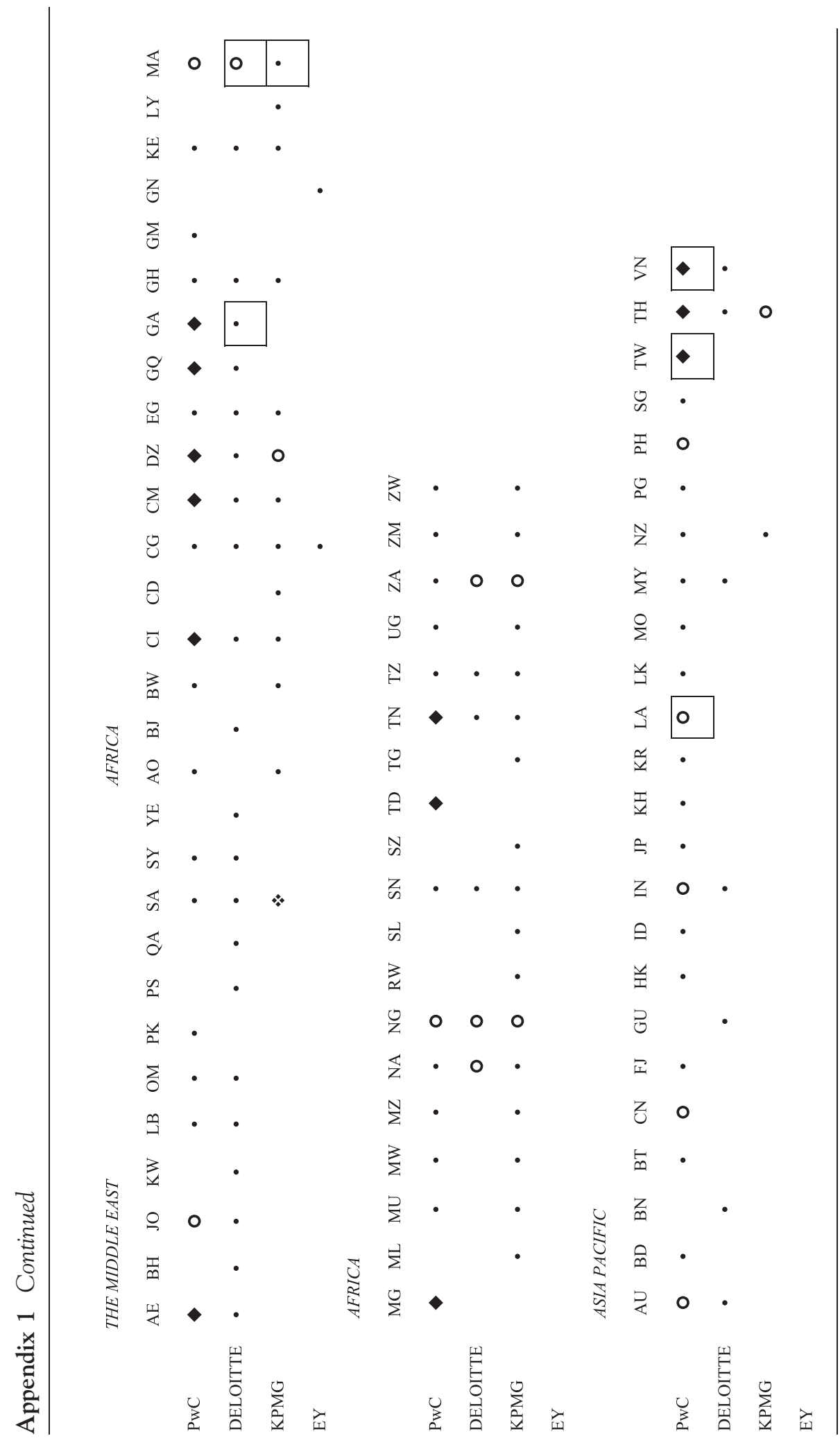




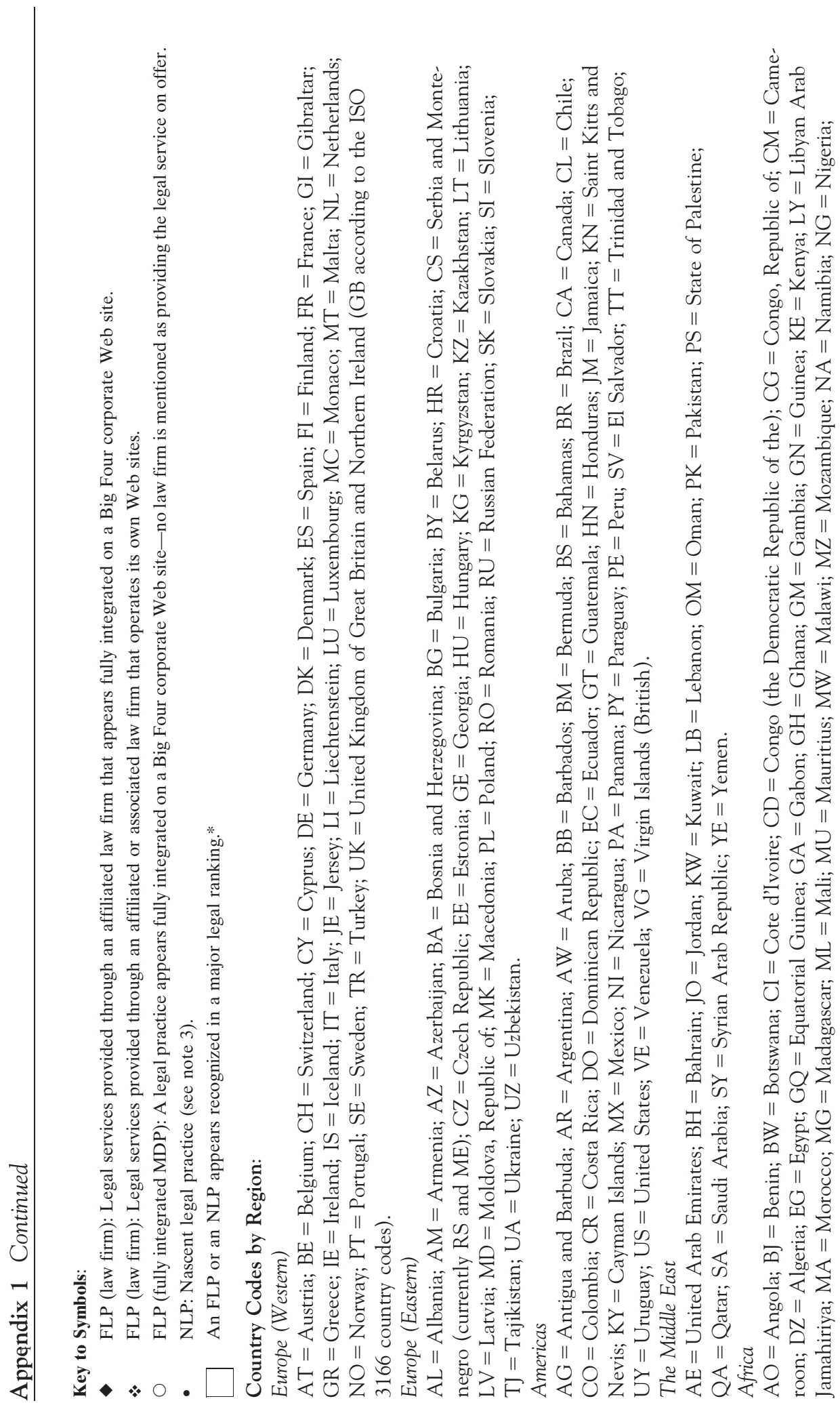


1022 LAW \& SOCIAL INQUIRY

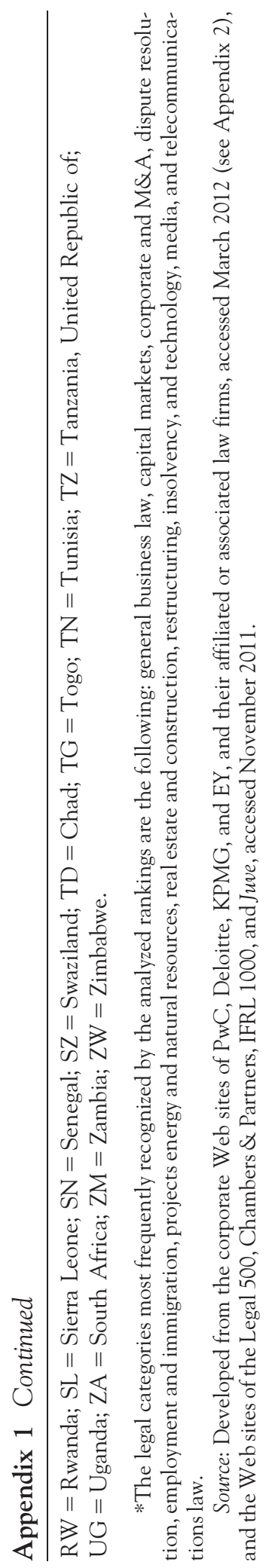


The Integration of Law into Global Business Solutions

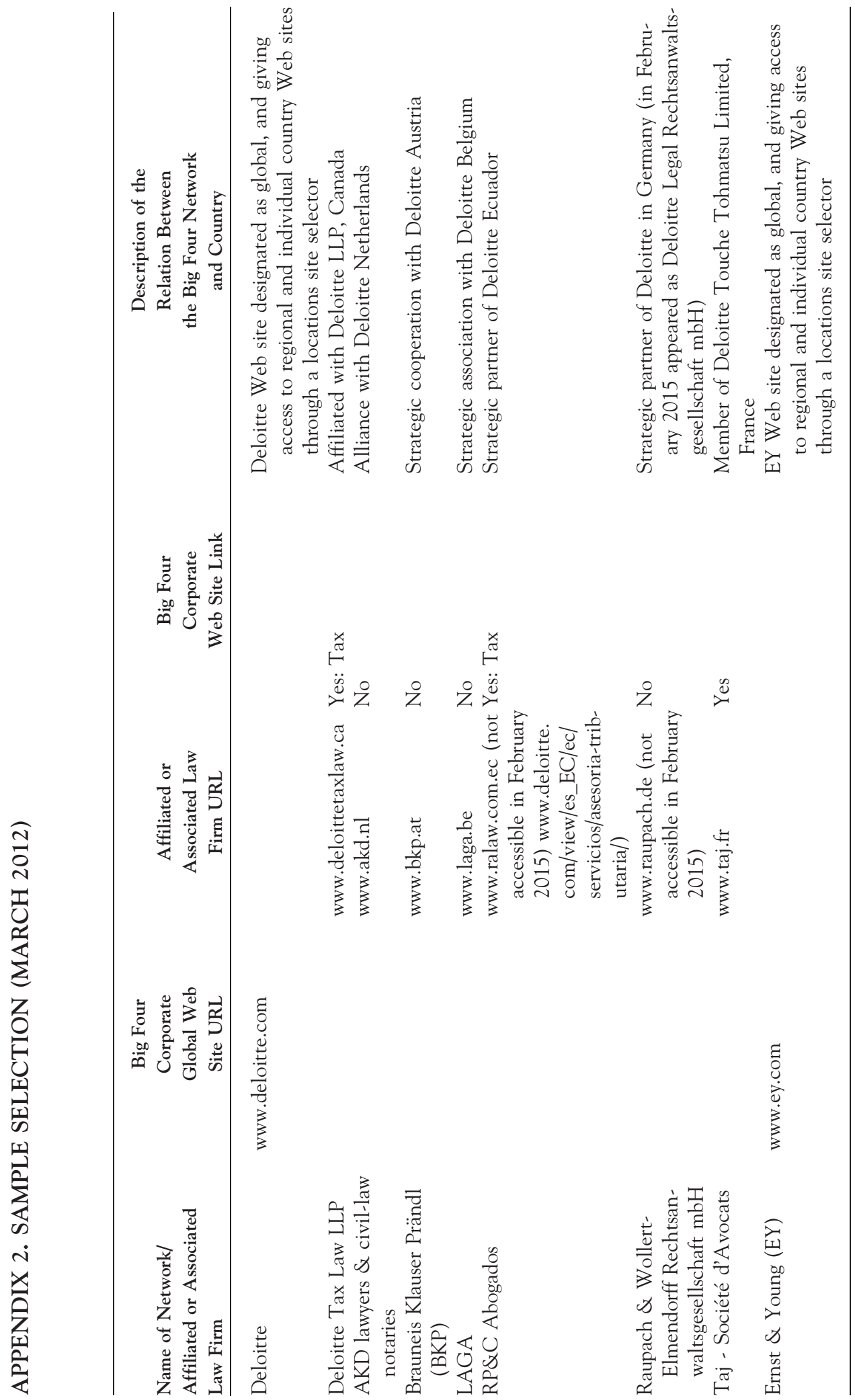




\section{LAW \& SOCIAL INQUIRY}

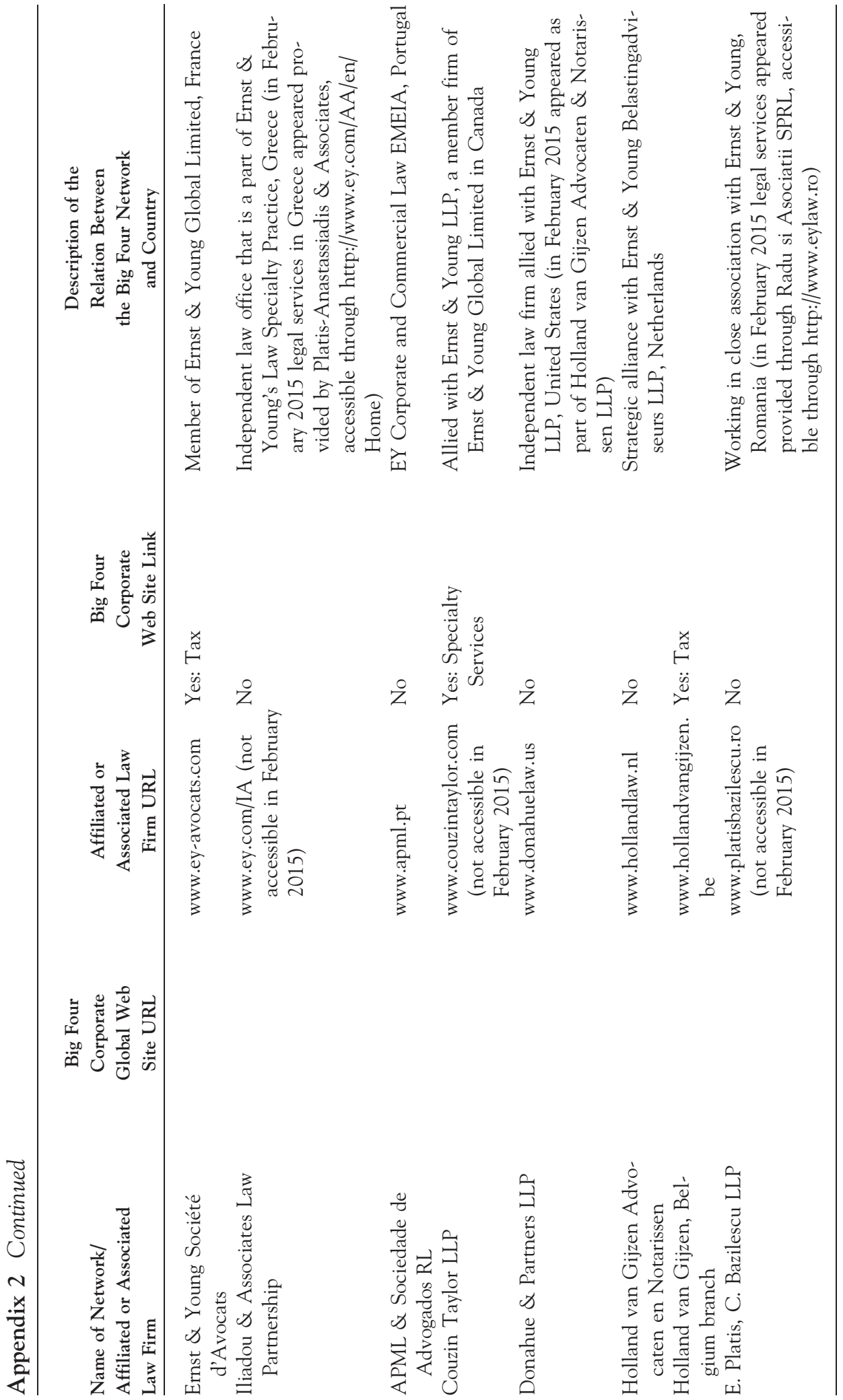


The Integration of Law into Global Business Solutions

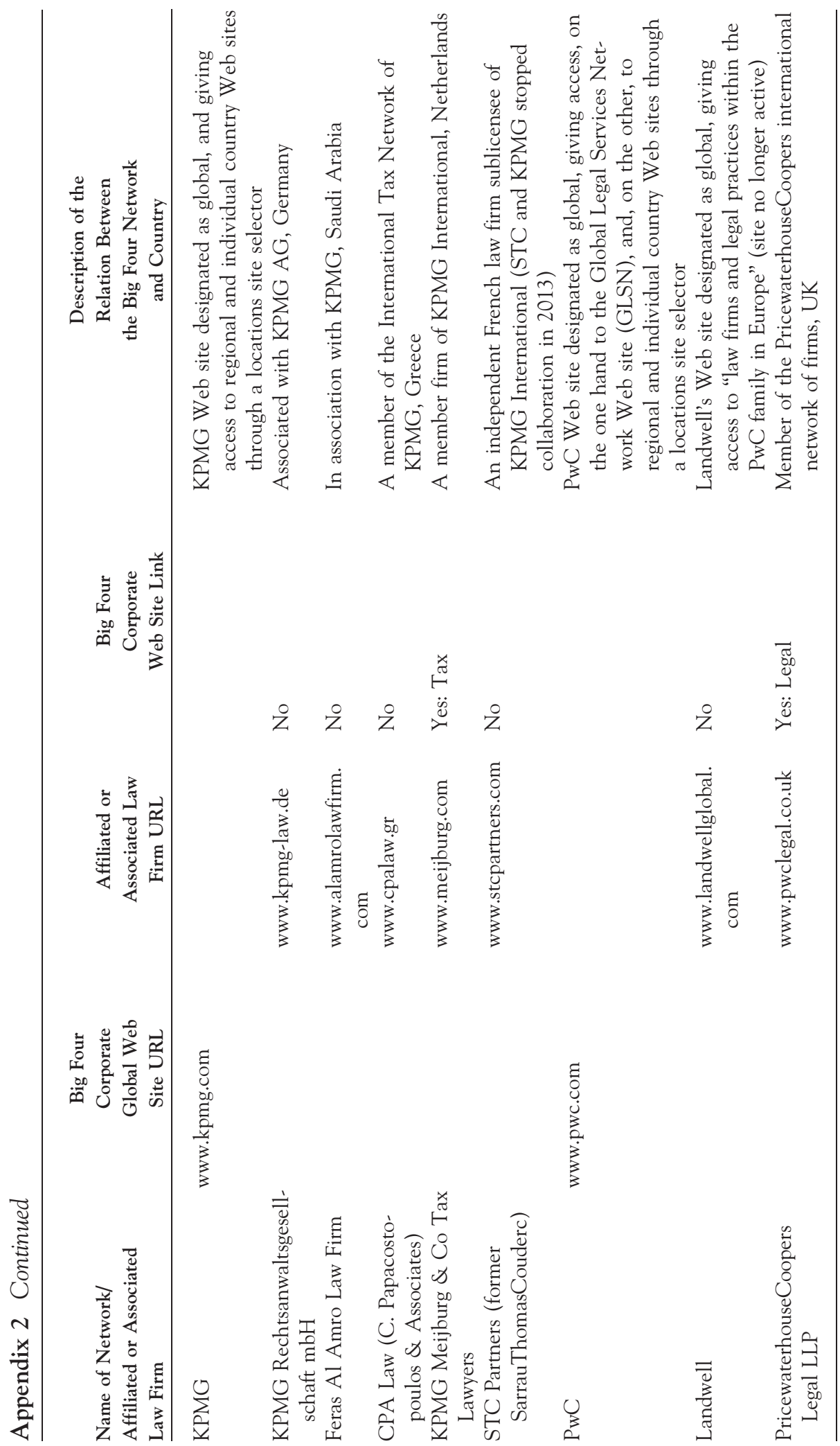


1026 LAW \& SOCIAL INQUIRY

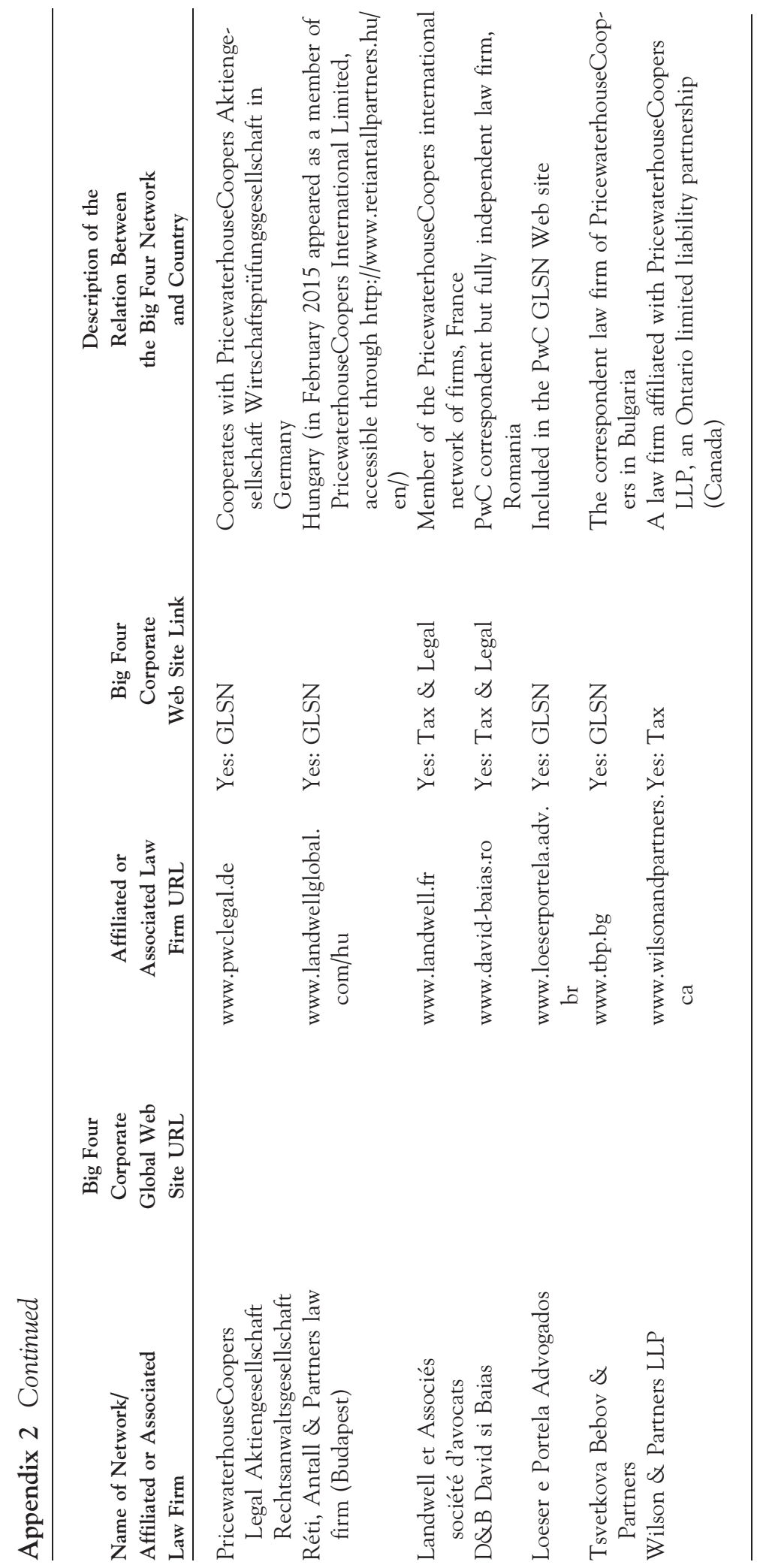

